
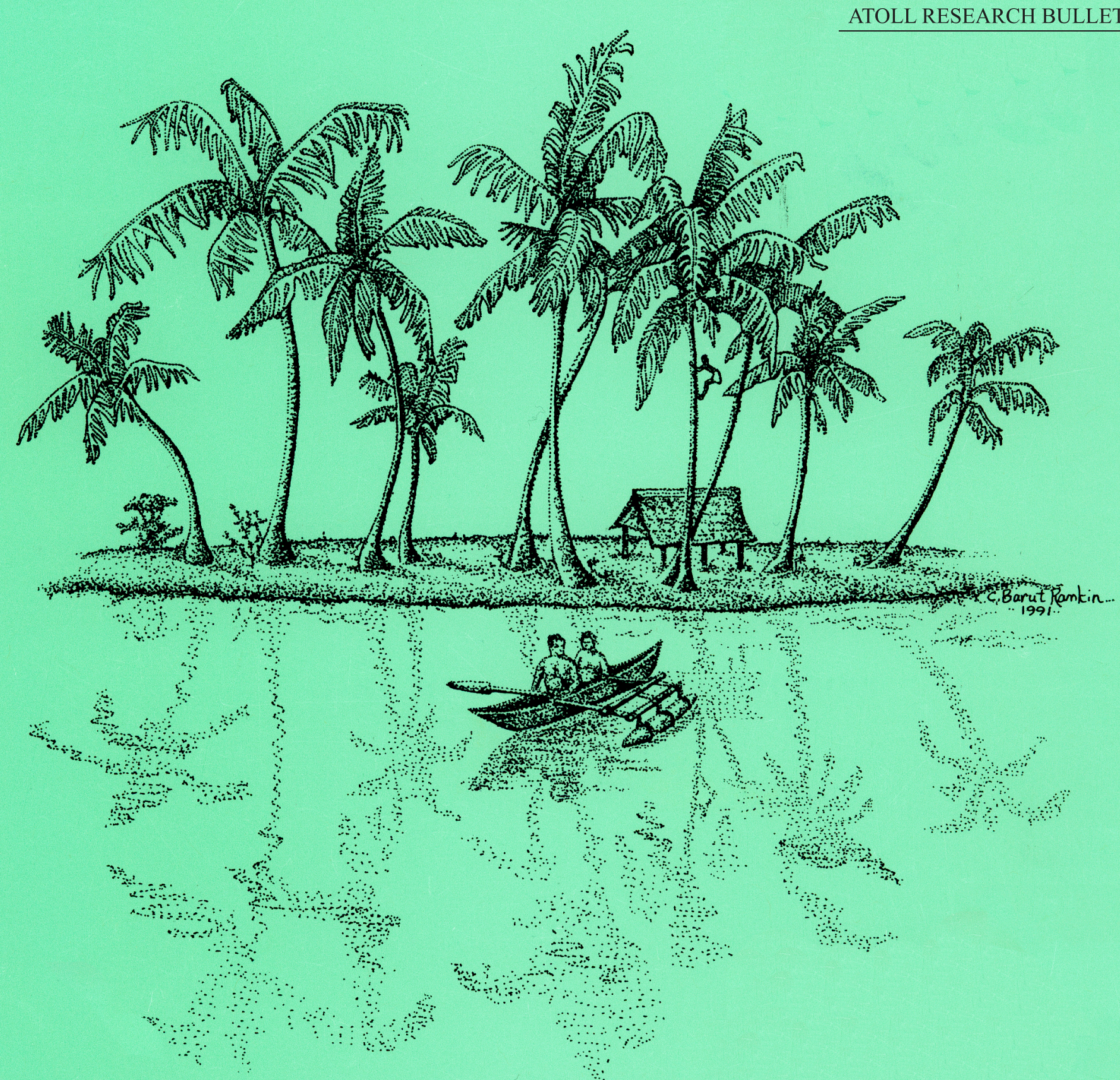

SHALLOW WATER LAGOON AND REEF FISHES OBSERVED AT NUKUNONU ATOLL, TOKELAU

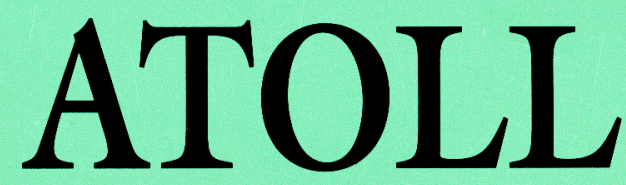

Hickson Fergusson

RESEARCH

Smithsonian Institution
Scholarly Press

BULLETIN 


\section{SHALLOW WATER LAGOON AND REEF FISHES OBSERVED AT NUKUNONU ATOLL, TOKELAU}

Hickson Fergusson

Atoll Research Bulletin No. 607 • 5 August 2015

Smithsonian Institution Scholarly Press

Washington, D.C. 
All statements made in papers published in the Atoll Research Bulletin are the sole responsibility of the authors and do not necessarily represent the views of the Smithsonian Institution or of the editors of the bulletin. Articles submitted for publication in the Atoll Research Bulletin should be original papers and must be made available by authors for open access publication. Manuscripts should be consistent with the "Author Formatting Guidelines for Publication in the Atoll Research Bulletin." All submissions to the bulletin are peer reviewed and, after revision, are evaluated prior to acceptance and publication through the publisher's open access portal, Open SI (http://opensi.si.edu).

Published by SMITHSONIAN INSTITUTION SCHOLARLY PRESS

P.O. Box 37012, MRC 957

Washington, D.C. 20013-7012

www.scholarlypress.si.edu

The rights to all text and images in this publication are owned either by the contributing authors or third parties. Fair use of materials is permitted for personal, educational, or noncommercial purposes. Users must cite author and source of content, must not alter or modify the content, and must comply with all other terms or restrictions that may be applicable. Users are responsible for securing permission from a rights holder for any other use.

ISSN: 0077-5630 (online) 


\title{
SHALLOW WATER LAGOON AND REEF FISHES OBSERVED AT NUKUNONU ATOLL, TOKELAU
}

\author{
HICKSON FERGUSSON ${ }^{1}$
}

\begin{abstract}
Tokelau comprises three small atolls in the central Pacific Ocean and is rarely visited by biologists due to its difficult access. Despite occasional visits by fisheries officers and some scientific collections made in the 1960s, very little has been recorded of the diversity of the fish fauna, and no checklist of the fishes of Tokelau has ever been published. In 2012 seven sites around Nukunonu atoll were snorkelled and the fish species recorded. A total of 143 species in 37 families were identified and the majority photographed, including four species with unusual or rare color forms and one hybrid. The species recorded indicate a diverse fish fauna comparable to those of Tokelau's neighbors. Using the results of this study, the specimens held in the scientific collections, and species mentioned in the literature, a provisional checklist of the fishes of Tokelau has been developed.
\end{abstract}

\section{INTRODUCTION}

Tokelau is a non-self-governing territory of New Zealand (McQuarrie, 2007) consisting of three atolls located in the central Pacific between $8^{\circ} \mathrm{S}$ and $10^{\circ} \mathrm{S}$ and $171^{\circ} \mathrm{W}$ and $173^{\circ} \mathrm{W}$ (van Pel, 1958; Ono and Addison, 2009; OCOG, 2010; Zylich et al., 2011; Pasilio et al., 2013). The three atolls-Atafu, Nukunonu, and Fakaofo-lie roughly in a straight line with Atafu the northernmost, Nukunonu 90 kilometers to the southeast, and Fakaofo a farther 60 kilometers southeast. Fakaofo is approximately 500 kilometers north of Samoa (Yaldwyn and Wodzicki, 1979; Huntsman and Hooper, 1996; Huntsman and Kalolo, 2007). Other neighbors include Wallis Island (Uvea) of Wallis and Futuna in the southwest, Tuvalu directly westward, and the largely uninhabited Phoenix Islands 400 kilometers north of Atafu (Figure 1).

Each of Tokelau's three atolls consists of a ring-shaped coral reef surrounding a central lagoon (Yaldwyn and Wodzicki, 1979; Ono and Addison, 2009). Scattered along the reef top are many small islets (motu), some with vegetation and others bare. The population of each atoll inhabits only one or two of these islets. The total land area of Tokelau is very small—only $12 \mathrm{~km}^{2}$ —with most islets less than 200 meters wide and often not very much longer (although some are a few kilometers in length).

Nukunonu, the largest of the three atolls with a land area of around $4.5 \mathrm{~km}^{2}$ and a $109 \mathrm{~km}^{2}$ lagoon (Huntsman and Hooper, 1996), is $16 \mathrm{~km}$ across at its greatest width (McQuarrie, 2007). It has more than 30 small islets, the largest of which is only $1.5 \mathrm{~km}^{2}$ (Yaldwyn and Wodzicki, 1979). The population of around 300 are confined to Nukunonu Village on the islets of Vao and Motuhaga in the southwest of the atoll (Figures 2 and 3).

Because of the small size of the islets, none of the atolls in Tokelau have ever had an airstrip (McQuarrie, 2007; Pasilio et al., 2013). Furthermore, none of the three atolls have a deepwater passage

${ }^{1}$ PO Box 295, Macarthur Square, NSW 2560, Australia

hix63@bigpond.com 

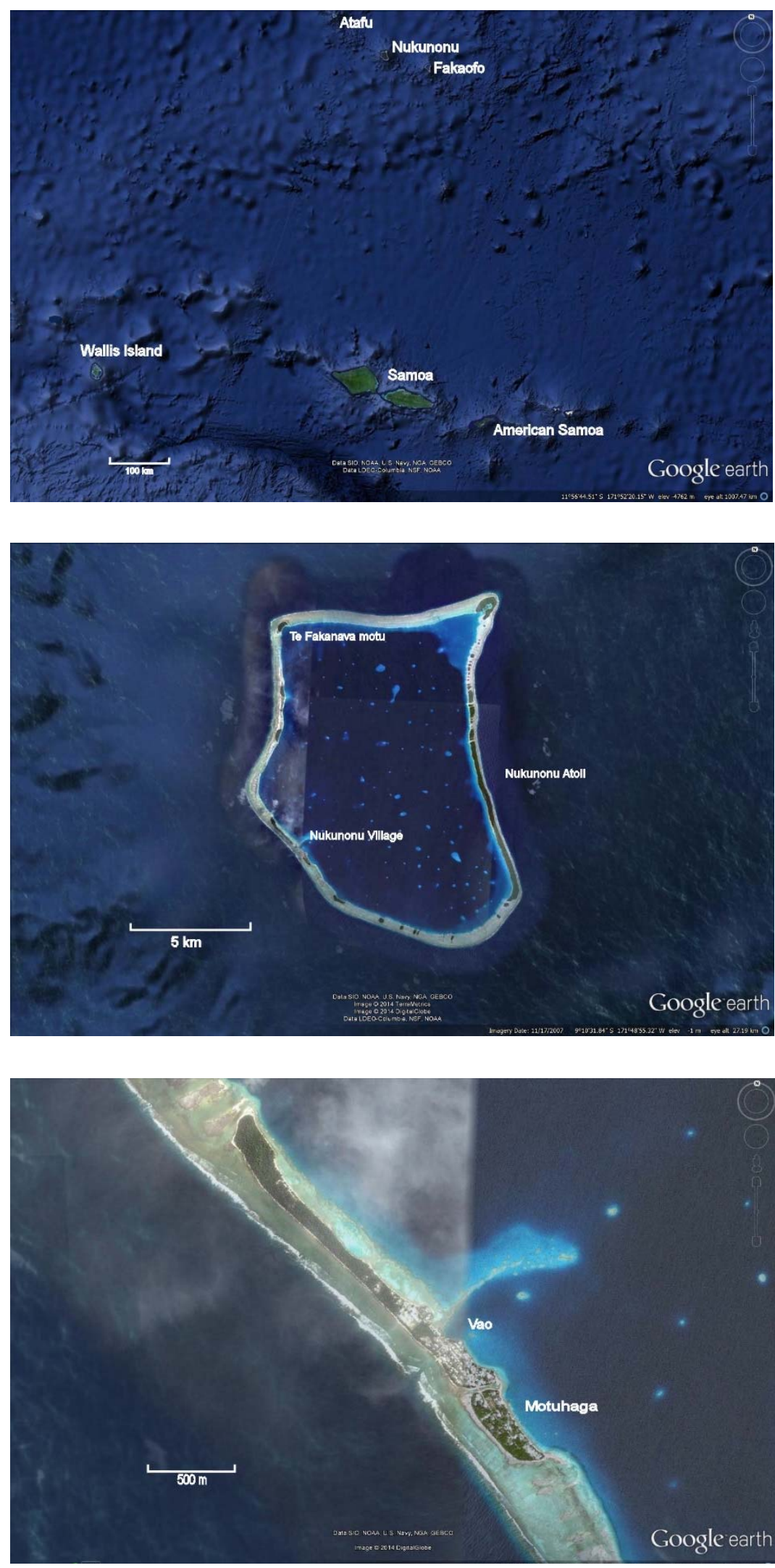

Figure 1. Tokelau in relation to Samoa. Fakaofo is 500 kilometers north of Samoa. The ocean around and between the atolls is 4,000 meters deep (Robertson and Kibblewhite, 1966). Image from Google Earth. Data from SIO, NOAA, U.S. Navy, NGA, GEBCO, LDEO-Columbia, NSF.

Figure 2. Nukunonu Atoll is the largest of the atolls with an area of $109 \mathrm{~km}^{2}$. The village is on the southwest islets. Although the population live on only two neighboring islets, they regularly visit the other islets to fish or collect coconuts. Image from Google Earth. Image (C) 2014 TerraMetrics. Image (C) 2014 DigitalGlobe. Data from SIO, NOAA, U.S. Navy, NGA, GEBCO, LDEO-Columbia, NSF.

Figure 3. Nukunonu Village, on the islets of Vao and Motuhaga. Image from Google Earth. Image (C) 2014 DigitalGlobe. Data from SIO, NOAA, U.S. Navy, NGA, GEBCO. 
for ships to pass through the reef and into the lagoon (van Pel, 1958; Huntsman and Hooper, 1996; Passfield, 1998; Pasilio et al., 2013) and there is no safe anchorage for ships outside the narrow reef as it drops sharply into the ocean depths (McQuarrie, 2007). This lack of accessibility has resulted in Tokelau remaining largely isolated from the rest of the world: a small, twice-monthly cargo ship from Apia, Samoa, is its only contact. Even this cargo ship is unable to dock or moor to a buoy; a barge (a large, flatbottomed aluminium boat with outboard motors) from the island pulls alongside the larger ship to allow passengers and goods to be transferred between the two vessels. The barge then returns to the atoll through a shallow channel dynamited in the reef flat for this purpose (McQuarrie, 2007). Presumably as a consequence of this difficult access, very few zoological studies have been conducted in Tokelau.

During the 1960s, scientific collections of fishes were made on all three atolls. The Smithsonian's National Museum of Natural History lists 239 lots (representing 1,657 specimens) in their collection, with all but eight collected in 1965 (NMNH, 2015). Likewise, the Academy of Natural Sciences in Philadelphia has 76 lots collected between 1960 and 1965 (ANS, 2015) and the California Academy of Sciences has two lots (D. Catania, personal communication). The Natural History Museum in England has nine specimens that were registered into the collection in 1930 (J. Maclaine, pers. comm.). No publications or reports have been made about any of these collections.

The few publications of the marine fauna of Tokelau tend to be concerned with fisheries in general (van Pel, 1958; Hinds, 1971; Gillett, 1990; Chapman et al., 2005; Pasilio et al., 2013) and commercially valuable fish species in particular (Tuna Programme, 1983; Gillett, 1985; Passfield, 1998; Zylich et al., 2011). No comprehensive checklist appears to exist, although Passfield (1998) compiled a list of Tokelauan fish names derived from multiple sources (including the Tokelau Dictionary [Simona, 1986] and his own questionnaires). He also conducted surveys of Fakaofo's lagoon and reef; however, it is unclear from the list which species he actually sighted, and many of the fish are not identified to species level. Similarly, Ono and Addison (2009) compiled a list of fish names from the Tokelau Dictionary (Simona, 1986) and other sources and by showing Atafu fisherman illustrations of fish in books. However, the two books used were guides to fishes of Southeast Asia and Japan; consequently their list includes at least 30 species of fish not found in this part of the Pacific Ocean.

The goal of this fish survey is therefore to provide a comprehensive inventory of reef fishes inhabiting Nukunonu Atoll.

\section{MATERIALS AND METHODS}

This author visited Nukunonu Atoll from 22 August 2012 to 7 September 2012 and took the opportunity to photograph and observe the lagoon and reef fishes in order to produce a record of the species found on this atoll. Accommodation was provided on Motuhaga (Figure 2) and four of the sites were adjacent to this islet. On this islet and the neighboring Vao, the reef has three zones on the ocean side. The first is a conglomerate platform, the remains of the reef that were exposed several thousand years ago when the sea levels in the Pacific dropped (Woodroffe and Biribo, 2011). Projecting out from under the islet like a ledge, it is usually just above the high tide level, but during spring tides the water may break over the edge, and during storm surges the platform may be completely submerged. Seaward of the platform is a reef flat that is shallowly submerged at low tide with some rocks and corals exposed. The seaward edge beyond the low algal crest is characterized by spurs and grooves, and below this is a narrow fore-reef with extensive hard coral cover. The outer edge of the fore-reef is a vertical drop-off. On the lagoon side of the islet the conglomerate platform is covered by a narrow beach composed of coral 
rubble and sand; beneath the waterline is a sandy substrate that angles sharply into the lagoon. Patch reefs and pinnacles, none of which were seen to break the water's surface, occur within the lagoon.

There are no dive facilities or scuba equipment in Tokelau so most observations in this study were made by snorkelling from the surface down to about six or seven meters. Other observations were made by walking the reef flats or alongside the channels or by observing fish that had been caught by the locals. Snorkelling was conducted for a total of more than 20 hours at seven sites, including three sites in the lagoon, a shallow channel between the lagoon and the reef flat, the reef flat, a manmade channel in the reef flat, and a single site on the outer reef (Table 1; Figures 4 and 5). Further observations of the individual sites are in Appendix A.

No fish were collected but most species were photographed. While the majority could be identified visually, these identifications are provisional; sampling and analysis of morphometrics, meristics, and DNA are required to confirm identifications. Fish references used for identifications include Allen et al. (2003) and Randall (2005).

Photography was taken with either a Canon D20 compact underwater camera or a Canon 550D camera and a Canon 100mm macro lens in a Nauticam waterproof housing with an Inon Z240 strobe. A GoPro Hero2 on a chest harness recorded movie images of most snorkelling sessions and on a few occasions was removed from the harness, attached to a weight, positioned in front of some coral, and left recording for a short period. These recordings were later used to confirm identifications of species that were not photographed and, in one case, a cryptic species that the author did not see.

Table 1. Site coordinates, depth, visitation details. Depths are estimates and are provided for illustrative purposes only.

\begin{tabular}{|c|c|c|c|c|c|}
\hline & Location & GPS Coordinates & $\begin{array}{c}\text { Max Depth } \\
\text { (m) }\end{array}$ & Date(s) & $\begin{array}{c}\text { Duration } \\
\text { (min) }\end{array}$ \\
\hline Site 1 & Lagoon & $\begin{array}{l}9^{\circ} 12^{\prime} 5.7^{\prime \prime} \mathrm{S} \\
171^{\circ} 50^{\prime} 46.01^{\prime \prime} \mathrm{W}\end{array}$ & 5 & $\begin{array}{l}8 / 23 / 12 \\
8 / 24 / 12 \\
\end{array}$ & $\begin{array}{r}34 \\
140 \\
\end{array}$ \\
\hline Site 2 & Channel & $\begin{array}{l}9^{\circ} 12^{\prime} 5.7^{\prime \prime} \mathrm{S} \\
171^{\circ} 50^{\prime} 46.01^{\prime \prime} \mathrm{W} \\
\text { to } \\
9^{\circ} 12^{\prime} 8.23^{\prime \prime} \mathrm{S} \\
171^{\circ} 50^{\prime} 53.42^{\prime \prime} \mathrm{W}\end{array}$ & 1 & numerous & various \\
\hline Site 3 & Reef flat & $\begin{array}{l}9^{\circ} 12^{\prime} 8.23^{\prime \prime} \mathrm{S} \\
171^{\circ} 50^{\prime} 53.42^{\prime \prime} \mathrm{W} \\
\text { to } \\
9^{\circ} 12^{\prime} 19.9^{\prime \prime} \mathrm{S} \\
171^{\circ} 50^{\prime} 42.65^{\prime \prime} \mathrm{W}\end{array}$ & 1 & $\begin{array}{l}8 / 23 / 12 \\
8 / 24 / 12 \\
8 / 30 / 12 \\
9 / 04 / 12 \\
9 / 05 / 12 \\
9 / 05 / 12 \\
\end{array}$ & $\begin{array}{r}23 \\
18 \\
189 \\
133 \\
77 \\
91 \\
\end{array}$ \\
\hline Site 4 & $\begin{array}{l}\text { Channel in } \\
\text { reef flat }\end{array}$ & $\begin{array}{l}9^{\circ} 12^{\prime} 0.43^{\prime \prime} \mathrm{S} \\
171^{\circ} 50^{\prime} 58.66^{\prime \prime} \mathrm{W}\end{array}$ & 4 & $\begin{array}{l}8 / 23 / 12 \\
8 / 27 / 12 \\
\end{array}$ & $\begin{array}{l}12 \\
89 \\
\end{array}$ \\
\hline Site 5 & Lagoon & $\begin{array}{l}9^{\circ} 7^{\prime} 3.52^{\prime \prime} \mathrm{S} \\
171^{\circ} 51^{\prime} 31.69^{\prime \prime} \mathrm{W}\end{array}$ & 8 & $8 / 25 / 12$ & 185 \\
\hline Site 6 & Lagoon & $\begin{array}{l}9^{\circ} 11^{\prime} 56.21^{\prime \prime} \mathrm{S} \\
171^{\circ} 50^{\prime} 56.89^{\prime \prime} \mathrm{W}\end{array}$ & 6 & $8 / 28 / 12$ & 90 \\
\hline Site 7 & Reef & $\begin{array}{l}9^{\circ} 12^{\prime} 14.37^{\prime \prime} \mathrm{S} \\
171^{\circ} 50^{\prime} 54.79^{\prime \prime} \mathrm{W}\end{array}$ & 8 & $\begin{array}{l}9 / 02 / 12 \\
9 / 03 / 12 \\
9 / 06 / 12\end{array}$ & $\begin{array}{l}19 \\
47 \\
77\end{array}$ \\
\hline
\end{tabular}




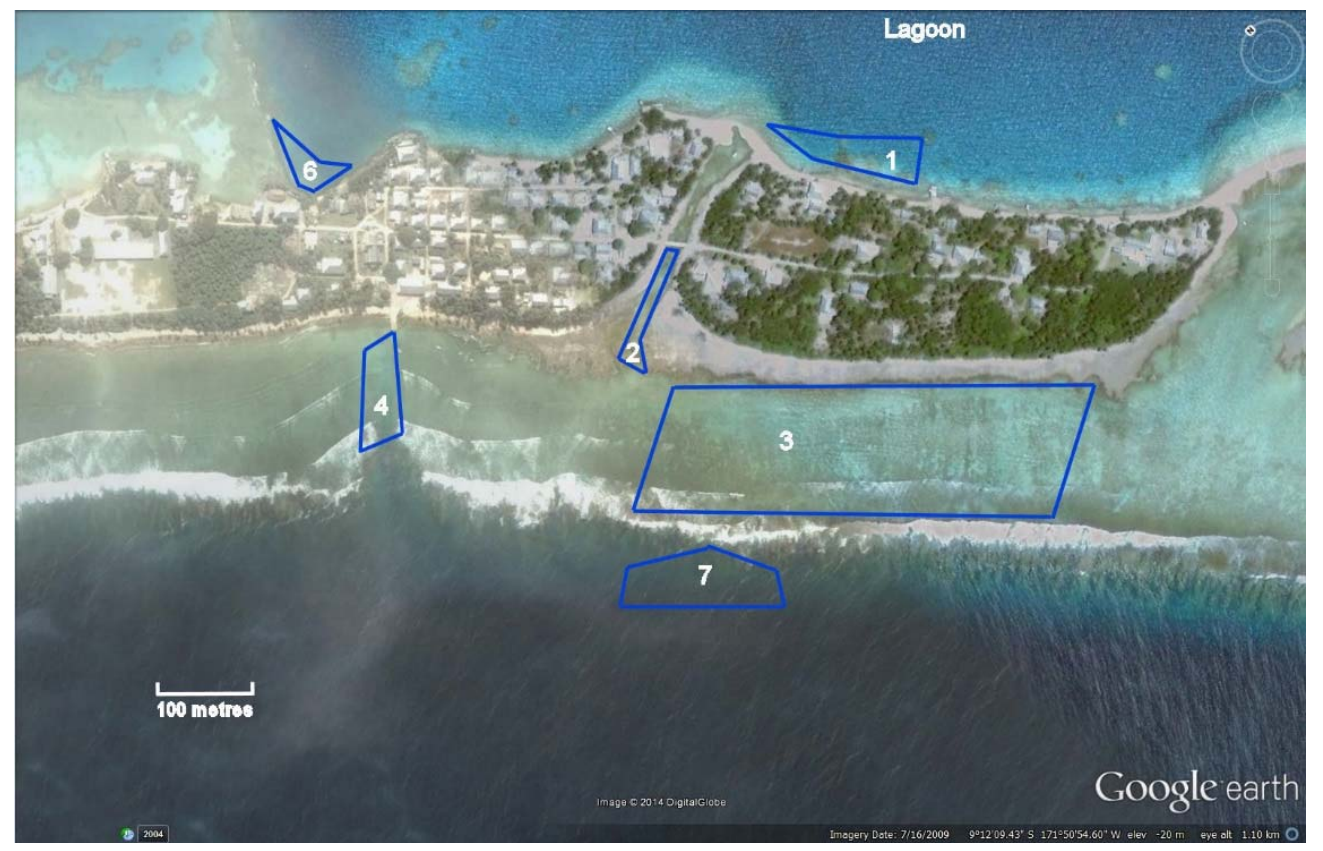

Figure 4. Survey sites around Nukunonu Village. Despite their proximity to each other, the sites varied in substrate, depth, water clarity, water movements, coral cover, shelter, and fish assemblages. See Table 1 and Appendix A for details of the individual sites. Image from Google Earth. Image (C) 2014 DigitalGlobe.

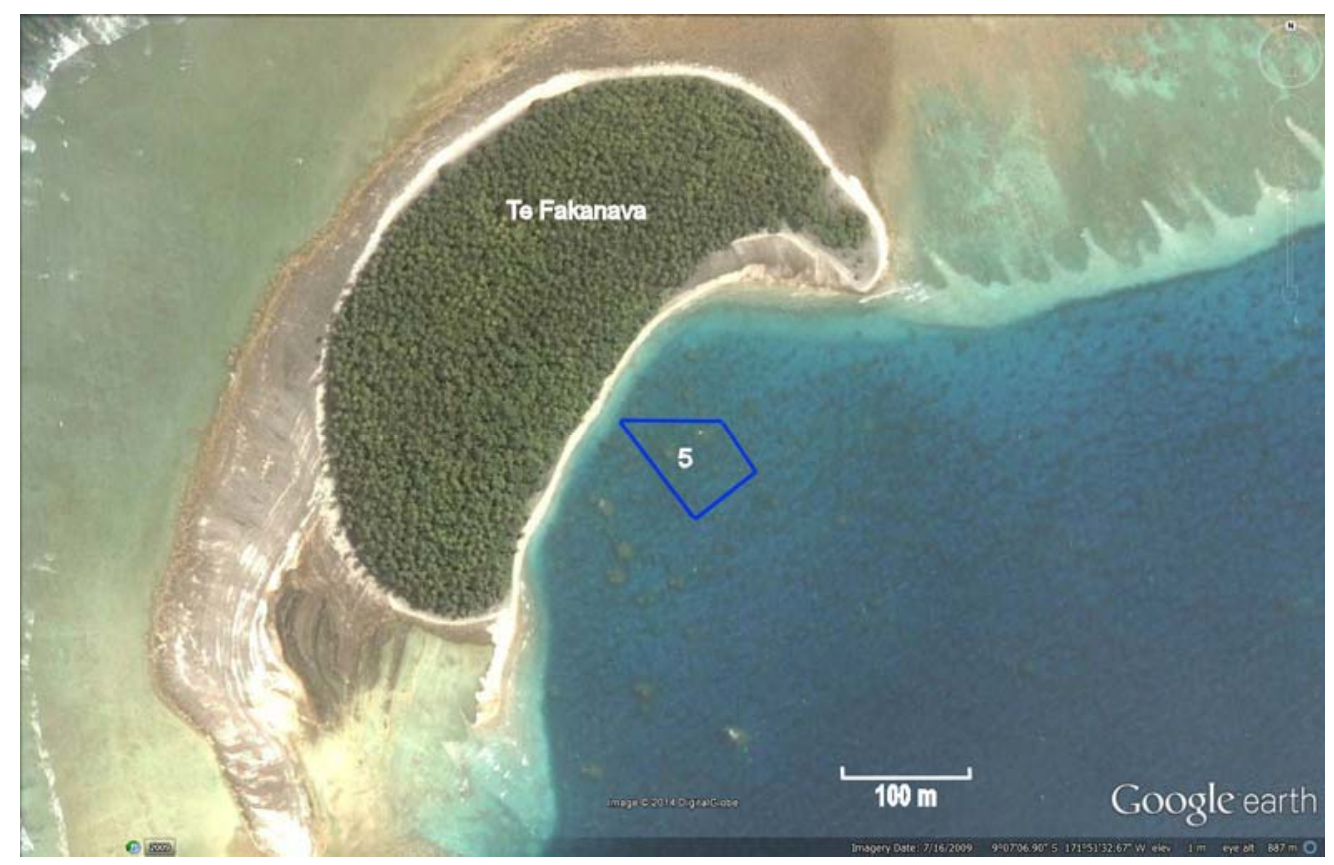

Figure 5. Survey site adjacent to Te Fakanava motu, five kilometers from the village. Pinnacles were common at this site and most fish species were sheltering in or around the pinnacles. Several species (including Gymnothorax javanicus, Kuhlia mugil, Dascyllus aruanus, Scarus schlegeli, S. frenatus, Valenciennea sexguttata, Ptereleotris evides, and Arothron meleagris) were seen at this site only. Image from Google Earth. Image (C) 2014 DigitalGlobe. 
Table 2. Fish species seen at different sites. (Continued)

Family

Species

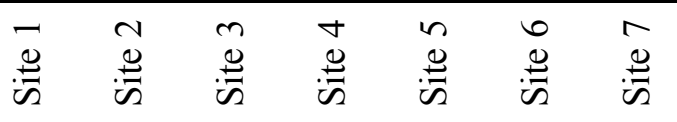

\section{Holocentridae (continued)}

Neoniphon opercularis (Valenciennes, 1831)

Neoniphon samara (Forsskål, 1775)

Sargocentron caudimaculatum (Rüppell, 1838)

Sargocentron microstoma (Günther, 1859)

Sargocentron spiniferum (Forsskål, 1775)

\section{Aulostomidae}

Aulostomus chinensis (Linnaeus, 1766)

\section{Fistulariidae}

Fistularia commersonii Rüppell, 1838

\section{Serranidae}

Cephalopholis argus Bloch and Schneider, 1801

Cephalopholis urodeta (Forster, 1801)

Epinephalus fuscoguttatus* (Forsskål, 1775)

Epinephalus hexagonatus (Forster, 1801)

Epinephalus merra Bloch, 1793

Epinephalus polyphekadion* (Bleeker, 1849)

\section{Apogonidae}

Unidentified apogonid

\section{Echeneidae}

Echeneis naucrates Linnaeus, 1758

\section{Carangidae}

Caranx melampygus Cuvier, 1833

Caranx sexfasciatus Quoy and Gaimard, 1825

Trachinotus baillonii (Lacepède, 1801)

\section{Lutjanidae}

Aphareus furca (Lacepède, 1801)

Aprion virescens* Valenciennes, 1830

Lutjanus bohar (Forsskål, 1775)

Lutjanus fulvus (Forster, 1801)

Lutjanus gibbus (Forsskål, 1775)

Lutjanus monostigma (Cuvier, 1828)

\section{Lethrinidae}

Gnathodentex aurolineatus (Lacepède, 1802)

Lethrinus xanthochilus Klunzinger, 1870

Monotaxis grandoculis (Forsskål, 1755)

\section{Mullidae}

Mulloidichthys flavolineatus (Lacepède, 1801)
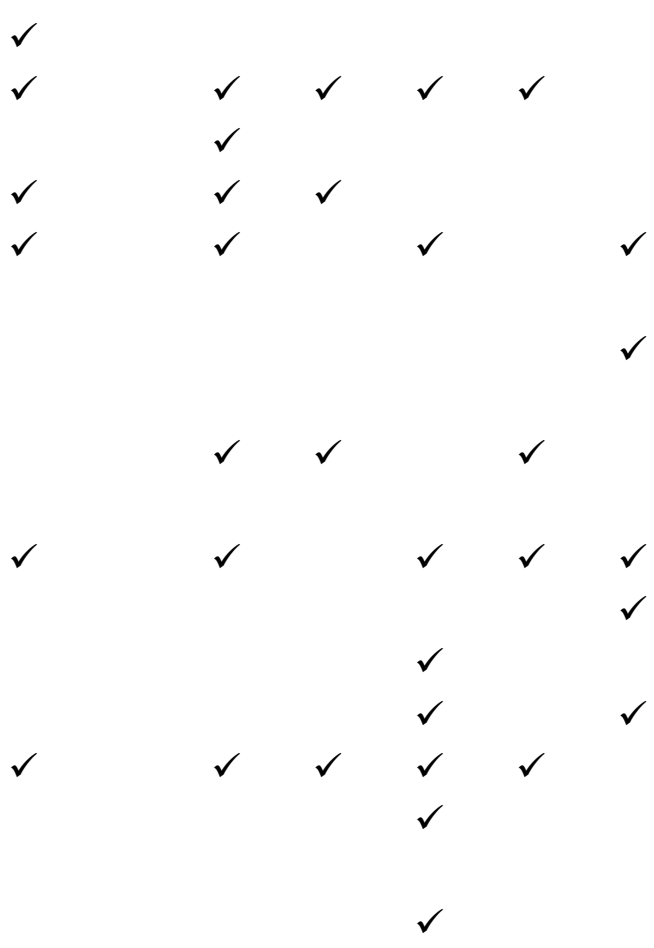
Table 2. Fish species seen at different sites. (Continued)

\section{Family}

Species

\begin{tabular}{|c|c|c|c|c|c|}
\hline$\stackrel{\oplus}{\stackrel{\oplus}{*}}$ & 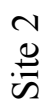 & $\stackrel{m}{\stackrel{\infty}{=}}$ & $\begin{array}{l}+ \\
\stackrel{\oplus}{\mathscr{S}}\end{array}$ & $\stackrel{\oplus}{\stackrel{\oplus}{\mathscr{S}}}$ & $\begin{array}{l}0 \\
\stackrel{0}{\mathscr{S}} \\
\stackrel{\mathscr{S}}{2}\end{array}$ \\
\hline
\end{tabular}

Mullidae (continued)

Mulloidichthys vanicolensis (Valenciennes, 1831)

Parupeneus barberinus (Lacepède, 1801)

Parupeneus cyclostomus (Lacepède, 1801)

Parupeneus insularis (Randall and Myers, 2002)

Parupeneus multifasciatus (Quoy and Gaimard, 1825)

\section{Kyphosidae}

Kyphosus vaigiensis* (Quoy and Gaimard, 1825)

\section{Chaetodontidae}

Chaetodon auriga Forsskål, 1775

Chaetodon citrinellus Cuvier, 1831

Chaetodon ephippium Cuvier, 1831

Chaetodon lunula (Lacepède, 1802)

Chaetodon lunulatus Quoy and Gaimard, 1825

Chaetodon ornatissimus Cuvier, 1831

Chaetodon quadrimaculatus Gray, 1831

Chaetodon reticulatus Cuvier, 1831

Chaetodon semeion Bleeker, 1855

Chaetodon ulietensis Cuvier, 1831

Chaetodon vagabundus Linnaeus, 1758

Forcipiger flavissimus Jordan and McGregor, 1898

Forcipiger longirostris (Broussonet, 1782)

Heniochus chrysostomus Cuvier, 1831

Heniochus monocerus Cuvier, 1831

\section{Pomacanthidae}

Centropyge flavissima (Cuvier, 1831)

Pygoplites diacanthus (Boddaert, 1772)

\section{Kuhliidae}

Kuhlia mugil (Forster, 1801)

\section{Cirrhitidae}

Neocirrhites armatus Castelnau, 1873

Paracirrhites arcatus (Cuvier, 1829)

Paracirrhites hemistictus (Günther, 1874)

\section{Pomacentridae}

Abudefduf septemfasciatus (Cuvier, 1830)

Abudefduf sordidus (Forsskål, 1775)

Chromis acares Randall and Swerdloff, 1973

Chromis margaritifer Fowler, 1946
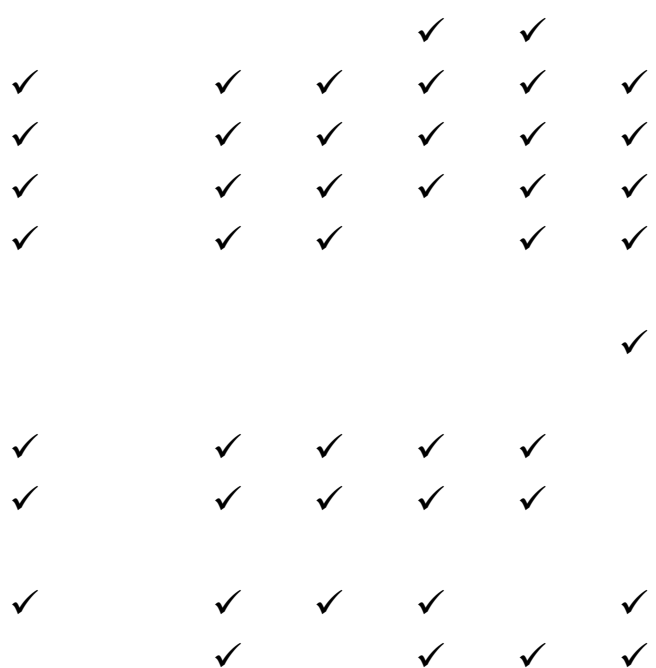

$\checkmark$
$\checkmark$
$v$
$v$
$v$
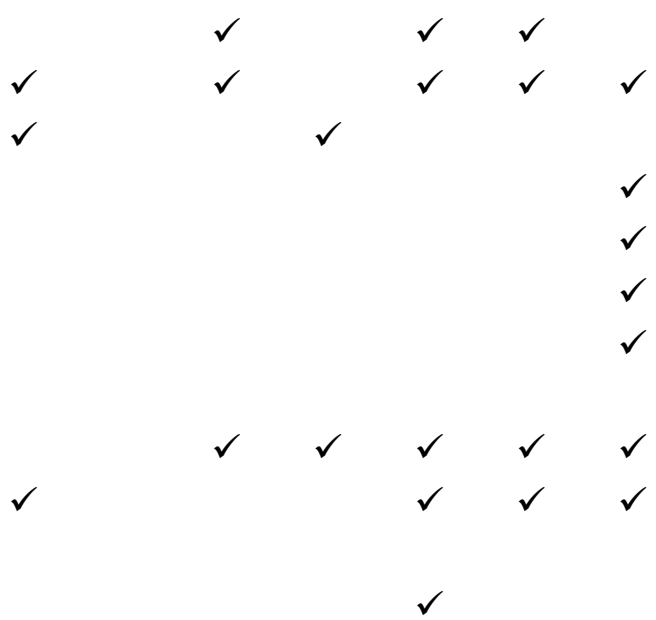
Table 2. Fish species seen at different sites. (Continued)

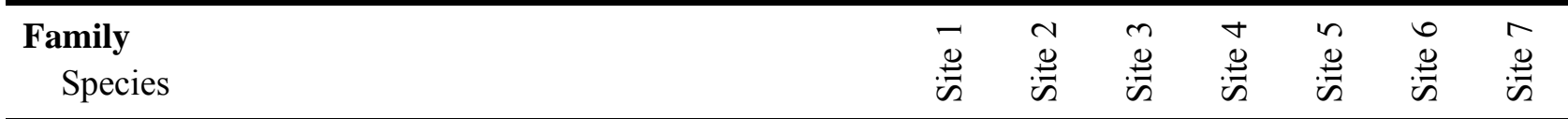

Pomacentridae (continued)

Chromis xanthura (Bleeker, 1854)

Chrysiptera glauca (Cuvier, 1830)

Dascyllus aruanus (Linnaeus, 1758)

Plectroglyphididon dickii (Liénard, 1839)

Pomacentrus pavo (Bloch, 1787)

Pomacentrus vaiuli Jordan and Seale, 1906

Stegastes albifasciatus (Schlegel and Müller, 1839)

Stegastes nigricans (Lacepède, 1802)

Chrysiptera sp. 1

Chrysiptera sp. 2

Chromis (?) sp.

\section{Labridae}

Anampses caeruleopunctatus Rüppell, 1829

Cheilinus fasciatus (Bloch, 1791)

Cheilinus trilobatus Lacepède, 1801

Cheilinus undulatus Rüppell, 1835

Coris aygula Lacepède, 1801

Coris gaimard (Quoy and Gaimard, 1824)

Epibulus insidiator (Pallas, 1770)

Gomphosus varius Lacepède, 1801

Halichoeres hortulanus (Lacepède, 1801)

Halichoeres margaritaceus (Valenciennes, 1839)

Halichoeres trimaculatus (Quoy and Gaimard, 1834)

Hemigymnus fasciatus (Bloch, 1792)

Labroides bicolor Fowler and Bean, 1928

Labroides dimidiatus (Valenciennes, 1839)

Labroides rubrolabiatus Randall, 1958

Oxycheilinus unifasciatus (Streets, 1877)

Stethojulis bandanensis (Bleeker, 1851)

Thalassoma amblycephalum (Bleeker, 1856)

Thalassoma hardwicke (Bennett, 1830)

Thalassoma purpureum (Forsskål, 1775)

Thalassoma quinquevittatum (Lay and Bennett, 1839)

Unidentified labrid

\section{Scaridae}

Cetoscarus ocellatus (Valenciennes, 1840)

Chlorurus frontalis (Valenciennes, 1840)

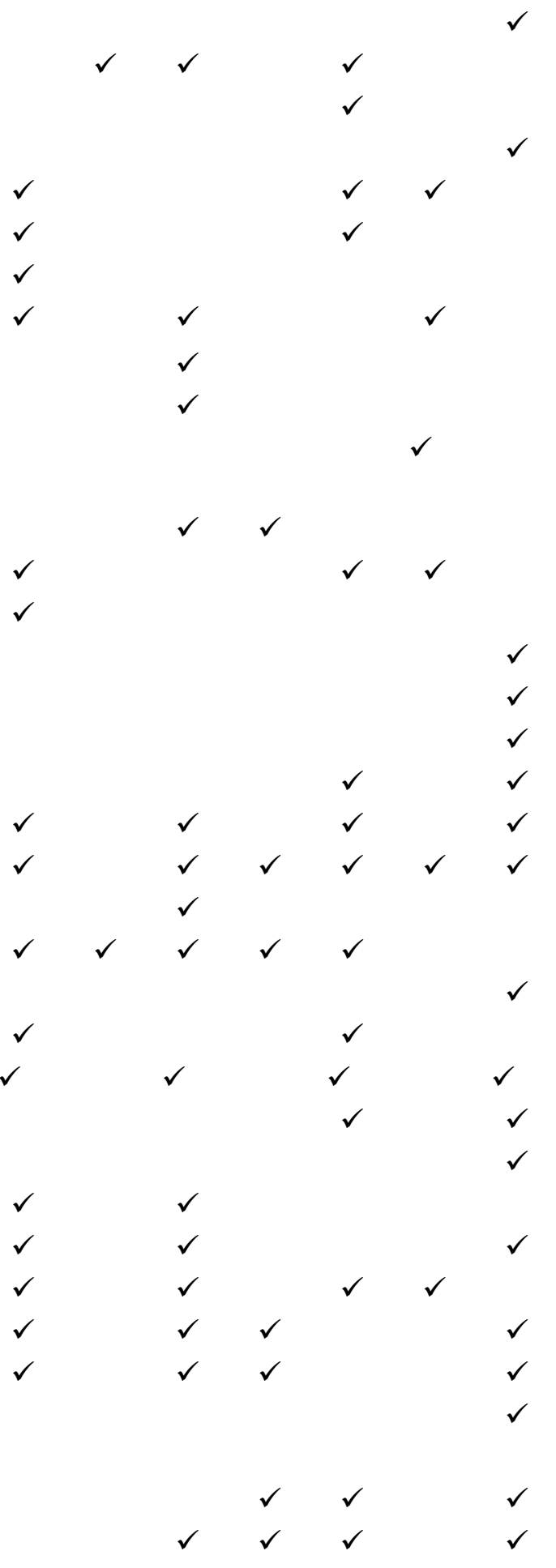

(Continued) 
Table 2. Fish species seen at different sites. (Continued)

\section{Family}

Species

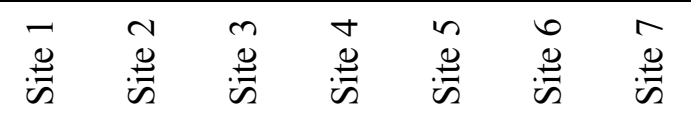

\section{Scaridae (continued)}

Chlorurus microrhinos (Bleeker, 1854)

Chlorurus spilurus (Valenciennes, 1840)

Hipposcarus longiceps (Valenciennes, 1840)

Scarus altipinnis (Steindachner, 1879)

Scarus frenatus Lacepède, 1802

Scarus psittacus Forsskål, 1775

Scarus rubroviolaceus Bleeker, 1847

Scarus schlegeli (Bleeker, 1861)

\section{Pinguipedidae}

Parapercis millepunctata (Günther, 1860)

\section{Blenniidae}

Blenniella paula (Bryan and Herre, 1903)

\section{Gobiidae}

Ctenogobiops feroculus* Lubbock and Polunin, 1977

Valenciennea sexguttata (Valenciennes, 1837)

\section{Ptereleotridae}

Ptereleotris evides (Jordan and Hubbs, 1925)

\section{Siganidae}

Unidentified siganid

\section{Zanclidae}

Zanclus cornutus (Linnaeus, 1758)

\section{Acanthuridae}

Acanthurus achilles Shaw, 1803

Acanthurus achilles $X$ A. nigricans

Acanthurus guttatus Forster, 1801

Acanthurus lineatus (Linnaeus, 1758)

Acanthurus nigricans (Linnaeus, 1758)

Acanthurus nigricauda Dunker and Mohr, 1929

Acanthurus nigros Günther, 1861

Acanthurus olivaceus Forster, 1801

Acanthurus pyroferus Kittlitz, 1834

Acanthurus triostegus (Linnaeus, 1758)

Acanthurus xanthopterus Valenciennes, 1835

Ctenochaetus striatus (Quoy and Gaimard, 1825)

Naso lituratus (Forster, 1801)

Naso unicornis (Forsskål, 1775)

Zebrasoma scopas (Cuvier, 1829)
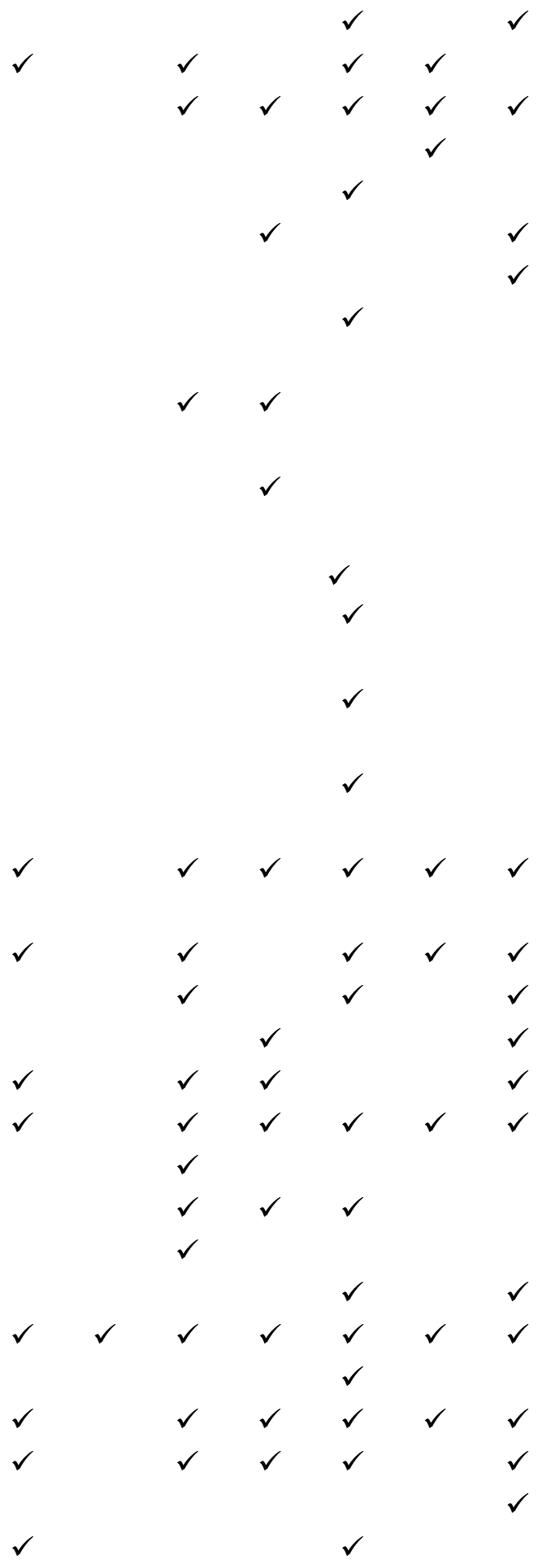

(Continued) 
Table 2. Fish species seen at different sites. (Continued)

\begin{tabular}{|c|c|c|c|c|c|c|c|}
\hline $\begin{array}{l}\text { Family } \\
\text { Species }\end{array}$ & $\stackrel{\oplus}{\stackrel{0}{=}}$ & 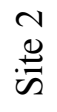 & 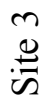 & $\stackrel{+}{\stackrel{\oplus}{=}}$ & $\stackrel{n}{\mathscr{n}}$ & $\begin{array}{l}0 \\
\stackrel{0}{=}\end{array}$ & 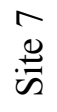 \\
\hline \multicolumn{8}{|l|}{ Acanthuridae (continued) } \\
\hline Zebrasoma veliferum (Bloch, 1795) & & & & $\checkmark$ & $\checkmark$ & & $\checkmark$ \\
\hline Unidentified acanthurid & & & & $\checkmark$ & $\checkmark$ & & \\
\hline \multicolumn{8}{|l|}{ Sphyraenidae } \\
\hline Sphyraena spp. & & & & & & & $\checkmark$ \\
\hline \multicolumn{8}{|l|}{ Bothidae } \\
\hline Bothus mancus (Broussonet, 1782) & & & & $\checkmark$ & & & \\
\hline \multicolumn{8}{|l|}{ Balistidae } \\
\hline Balistapus undulatus (Park, 1797) & & & & & $\checkmark$ & & $\checkmark$ \\
\hline Balistoides viridescens* (Bloch and Schneider, 1801) & & & & $\checkmark$ & & & \\
\hline Melichthys niger (Bloch, 1786) & & & & & & & $\checkmark$ \\
\hline Melichthys vidua (Solander and Richardson, 1845) & & & & $\checkmark$ & $\checkmark$ & & $\checkmark$ \\
\hline Pseudobalistes flavimarginatus (Rüppell, 1829) & & & & & $\checkmark$ & & $\checkmark$ \\
\hline Rhinecanthus aculeatus (Linnaeus, 1758) & $\checkmark$ & & $\checkmark$ & $\checkmark$ & $\checkmark$ & $\checkmark$ & \\
\hline Rhinecanthus retangulus (Bloch and Schneider, 1801) & & & $\checkmark$ & $\checkmark$ & & & $\checkmark$ \\
\hline Sufflamen bursa (Bloch and Schneider, 1801) & & & & & & & $\checkmark$ \\
\hline \multicolumn{8}{|l|}{ Monacanthidae } \\
\hline Aluterus scriptus (Osbeck, 1765) & & & & & & & $\checkmark$ \\
\hline Cantherhines dumerilii (Hollard, 1854) & & & $\checkmark$ & & & & $\checkmark$ \\
\hline \multicolumn{8}{|l|}{ Tetraodontidae } \\
\hline Arothron hispidus (Linnaeus, 1758) & & & & & & $\checkmark$ & \\
\hline Arothron meleagris (Lacepède, 1798) & & & & & $\checkmark$ & & \\
\hline Arothron nigropunctatus (Bloch and Schneider, 1801) & & $\checkmark$ & $\checkmark$ & & & & \\
\hline Canthigaster amboinensis (Bleeker, 1865) & & & $\checkmark$ & & & & \\
\hline Canthigaster solandri (Richardson, 1845) & & & $\checkmark$ & & & & \\
\hline \multicolumn{8}{|l|}{ Diodontidae } \\
\hline Diodon hystrix Linnaeus, 1758 & & & $\checkmark$ & & & & \\
\hline
\end{tabular}

\section{DISCUSSION}

A total of 143 species and one hybrid were identified, six of them tentatively. Two epinephalidsEpinephalus fuscoguttatus and E. polyphekadion - are similar and may be misidentified (Randall and Ben-Tuvia, 1983; Randall and Heemstra, 1991; Randall, 2005; Craig et al., 2011). Furthermore, the most common serranid sighted-E. merra - appeared to have a variable pattern, and some individuals identified as E. merra may prove to be another species. A brief glimpse of what was thought to be Aprion virescens may have been a misidentification, and the Kyphosus vaigensis may have actually been the similar K. biggibus or K. pacificus. The single Balistoides viridescens briefly seen at Site 4 was not viewed clearly due to the amount of sediment in the water but was identified tentatively by the obvious pale area on the body anterior to the caudal peduncle. 
A further 11 could not be confidently identified to species. The belonid is most likely Platybelone argalus, but neither photographs nor observations could confirm this. Myripristine holocentrids were seen at several sites and may represent more than one species, possibly Myripristis berndti or M. kuntee or both. One of the Chrysiptera species may be Chrysiptera brownriggi or C. unimaculata, and the Chromis is probably Chromis virescens. At most of the sites, one or more scarids defied identification, having variable color patterns that made positive identification difficult. One individual scarid, seen at Site 1, may have been Chlorurus bleekeri, although it lacked the distinctive green cheek markings. The acanthurid seen in reasonable numbers $(20+)$ at Site 4 was not seen clearly due to the sediment in the water but appeared to be black (or very dark) with a white ring around the base of the caudal fin. The species may have been Acanthurus nigricauda, although the A. nigricauda seen at Site 3 had a completely white tail and a more streamlined body shape; alternatively, it may have been A. blochi.

The hybrid Acanthurus achilles $X$ nigricans (Plates 1 and 2) was sighted at three different locationsSite 3 and Site 7, which are contiguous, and Site 5, which is approximately eight kilometers from the other sites — suggesting this may be a rare but not unusual occurrence. Randall (1960; 2001:15) reports this hybrid from the Phoenix Islands, the island of Hawaii, Caroline Atoll, and the Tuamotu Archipelago.

Some unusual coloration was observed in four species of fish. A lone Aphareus furca was sighted on the reef at Site 7 on two consecutive days. This species is normally a silvery color, but this individual was dusky with a reddish tinge and a bright yellow irregular splotch on the head just anterior to the first dorsal fin (Plates 3 and 4); this has been described as a rare color form (Randall, 2005:242). Examples of the red version of Chlorurus microrhinos were also sighted on the reef at Site 7. This morph is reported as an "occasional color morph" by Randall (2005:450) and as "generally rare" by Allen et al. (2003:177). The specimens of Abudefduf septemfasciatus that were seen all had irregular black markings on the posterior edges of the second dorsal, anal, and caudal fins, giving the fins a ragged appearance, as if they had been chewed (Plates 5 and 6). These markings do not appear to have been previously recorded, and both Allen and Randall have not seen it before (G. Allen, West Australian Museum, pers. comm.; J. E. Randall, Bishop Museum, pers. comm.). However, this author has seen this pattern in A. septemfasciatus in Niue, about 1,000 kilometers to the south. The tail of Acanthurus nigricauda usually is dark with a white ring at the base, but as mentioned above, those seen in Nukunonu have a completely white tail (Plates 7 and 8).

Visual assessments are an easy and effective way to rapidly assess and record common fish species, but pelagic and deepwater species are rarely sighted and small cryptic species are often overlooked (McDermond and Wass, 1986; Williams et al., 2006). However, Allen and Werner (2002) showed that the approximate total number of fish species in an area can be predicted by counting the number of species in six key families. Of the 154 species sighted, a total of 80 species were found in the six key families, and thus, using the formula for small reefs, the predicted total number of species expected for Nukunonu Atoll is 251 species, suggesting another 97 species are still to be recorded. This predicted total of 251 species is low compared to Tokelau's nearest neighbors: Samoa has 991, Wallis Island has 648, Tuvalu has 607, and the Phoenix Islands have 516 (Wass, 1984; Williams et al., 2006; Job and Ceccarelli, 2012; Allen and Bailey, 2011).

There are two reasons why this predicted total is less than half the known numbers of Tokelau's neighbors. As mentioned previously, deepwater and pelagic species as well as cryptic species are not recorded during shallow water visual surveys. Second, a limited number of sites were surveyed, and the windward reef was not visited at all. The coral composition on this exposed reef would be different from the single reef site visited in this survey, resulting in a differing assemblage of fish fauna. In contrast, Tokelau's neighbors have been surveyed more extensively (Schultz, 1943; Wass, 1984; Wantiez and Chauvet, 2003; Williams et al., 2006; Job and Ceccarelli, 2012; Allen and Bailey, 2011). 
Despite the relatively low number of species recorded for Nukunonu, the assemblage is similar to those of Tokelau's nearest neighbors. Comparing the species listed in Table 2 to published checklists for the fishes of Samoa (Wass, 1984), Wallis Island (Williams et al., 2006), Tuvalu (Job and Ceccarelli, 2012), and the Phoenix Islands (Allen and Bailey, 2011), reveals that $96 \%$ of the species seen in this study in Nukunonu are recorded in Samoa, 90\% in the waters around Wallis Island, 92\% in Tuvalu, and $95 \%$ in the Phoenix Islands. The species seen in Nukunonu but not recorded for Samoa were Epinephalus polyphekadion, Letherinus xanthochilus, Parupeneus multifasciatus, Ctenogobiops feroculus, and Ptereleotris evides. At Wallis Island Carcharhinus melanopterus, Crenimugil crenilabris, Neomyxus leuciscus, Epinephalus hexagonatus, Caranx sexfasciatus, Parupeneus insularis, Chaetodon quadrimaculatus, Paracirrhites hemistictus, Labroides rubrolabiatus, Chlorurus frontalis, Ctenogobiops feroculus, Acanthurus nigros, Bothus mancus, Melichthys niger, and Aluterus scriptus are not recorded. At Tuvalu Gymnothorax pictus, Neomyxus leuciscus, Stegastes albifasciatus, Labroides rubrolabiatus, Parapercis millepunctata, Bleniella paula, Valenciennea sexguttata, and Canthigaster amboinensis are not recorded. And absent in the Phoenix Islands are Parupeneus insularis, Pomacentrus vaiuli, Cheilinus fasciatus, C. trilobatus, Scarus schlegeli, Ctenogobiops feroculus, and Valenciennea sexguttata.

As would be expected on a small remote island, fishing is an important part of everyday life for the population (Huntsman and Hooper, 1996; Chapman et al., 2005; Elders, 2012), and fish make up a significant part of their diet (Passfield, 1998; Zylich et al., 2011). It was noted by Yaldwyn and Wodzicki (1979:9) that "there is a rich and varied lagoon and offshore fauna of marine fishes still undocumented," yet since that time there does not appear to have been an attempt to accurately document the species native to these atolls. Furthermore, in the Tokelau National Strategic Plan: 1 July 2010-30 June 2015 it is noted that coral bleaching is now an annual event and has led to "degradation of coral reefs both inside and outside the lagoon. ... This has greatly affected the quantity and quality of food supply from the inshore fish population. The life cycle of in-shore fish is also affected by the extreme weather conditions which has seen the decrease in the number and gradual disappearance of some species of fish from the lagoons" (OCOG, 2010:10).

Clearly, further research is needed, especially sampling specimens for collections to confirm identification. Documenting the fish fauna found deeper than 10 meters, surveying more sites, especially on the eastern reefs, and utilizing ichthyocides to sample small and cryptic fishes will give a better indication of the true number of species present in the waters of Nukunonu Atoll.

\section{ACKNOWLEDGMENTS}

In Nukunonu I am indebted to Mikaele Maiava and his mother, Maliana, who graciously allowed me to stay with them in their home for the duration of my stay. I thank Zac Patelesio, Pio Alainuuese, and Panapa Sakaria for their assistance while I was in Tokelau and Yevonna Ng Lam-Eteuati at the Tokelau Apia Liaison Office in Samoa. For identifications, information, and general ichthyological discussions, I thank Jack Randall, Gerry Allen, Mark McGrouther, Robert Gillett, Dave Catania, Mark Sabaj Perez and Kyle Luckinbill, Jeff Williams and Kris Murphy, and James Maclaine. Colin Woodroffe assisted with geomorphological terminology. Mark McGrouther and Jack Randall reviewed the initial draft and made a number of constructive suggestions. 


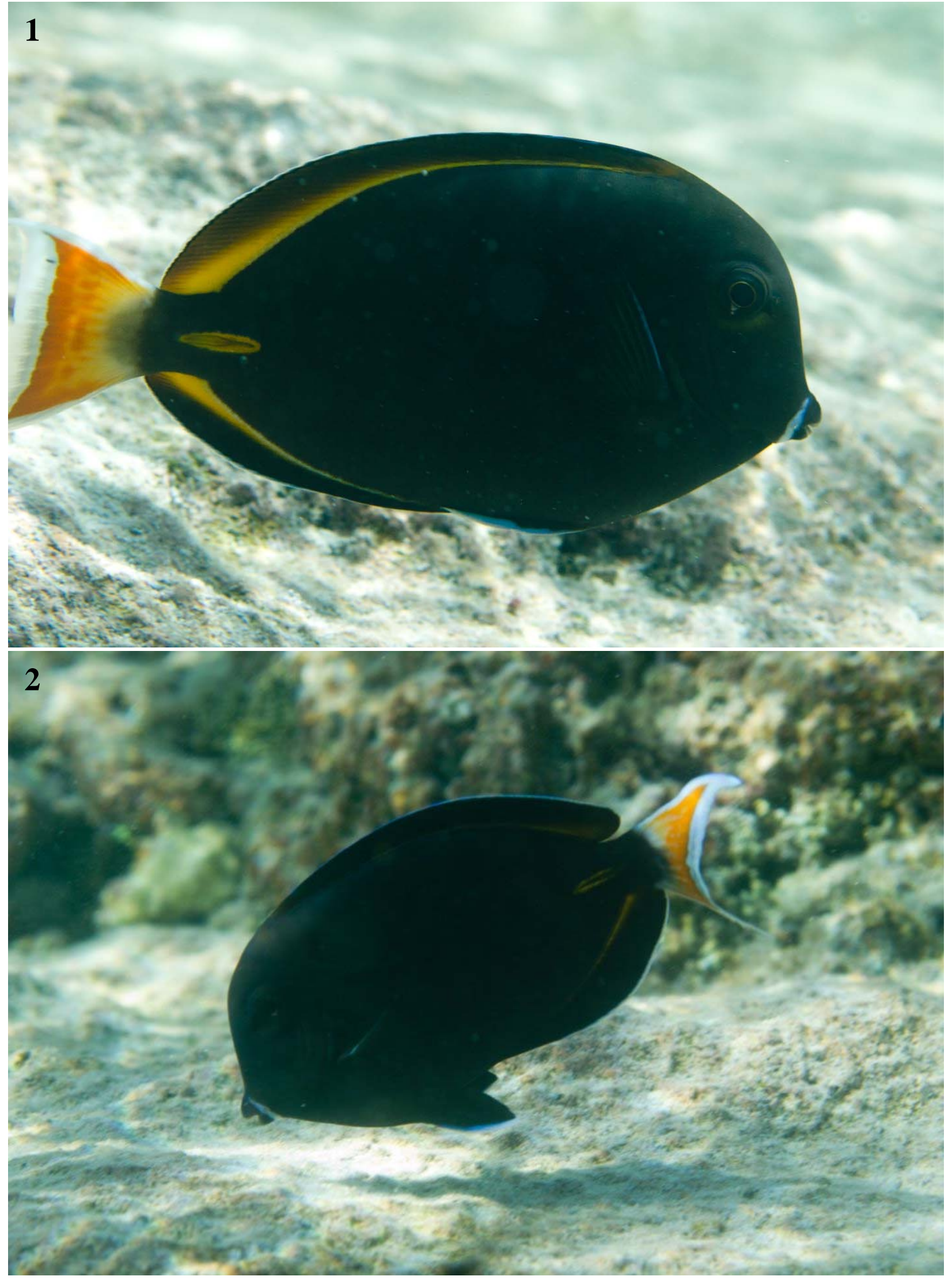

Plates 1 and 2. Hybrid surgeonfish, Acanthurus achilles X nigricans. Photos copyright of the author. 


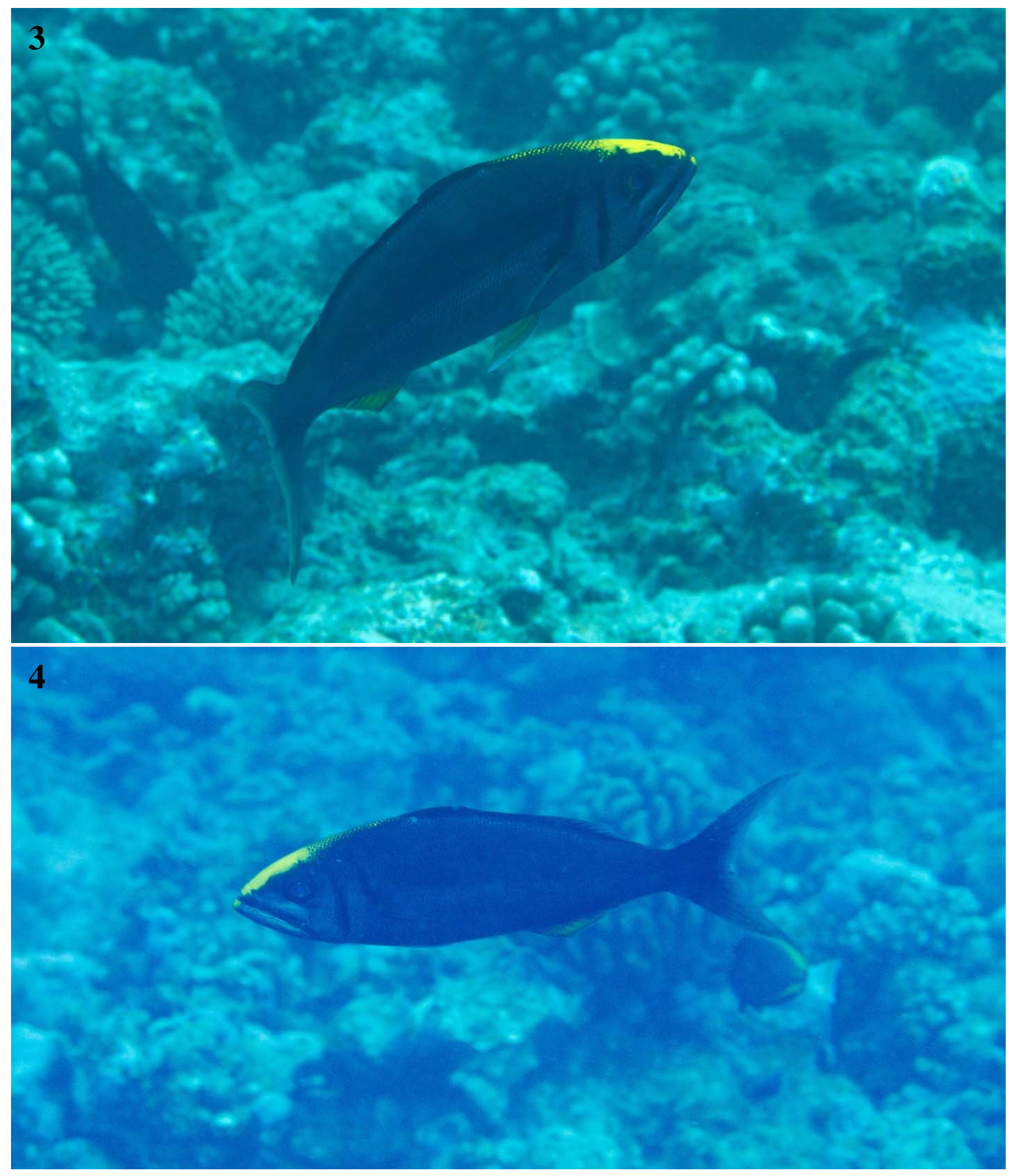

Plates 3 and 4. A rare color morph of Aphareus furca. Photos copyright of the author. 


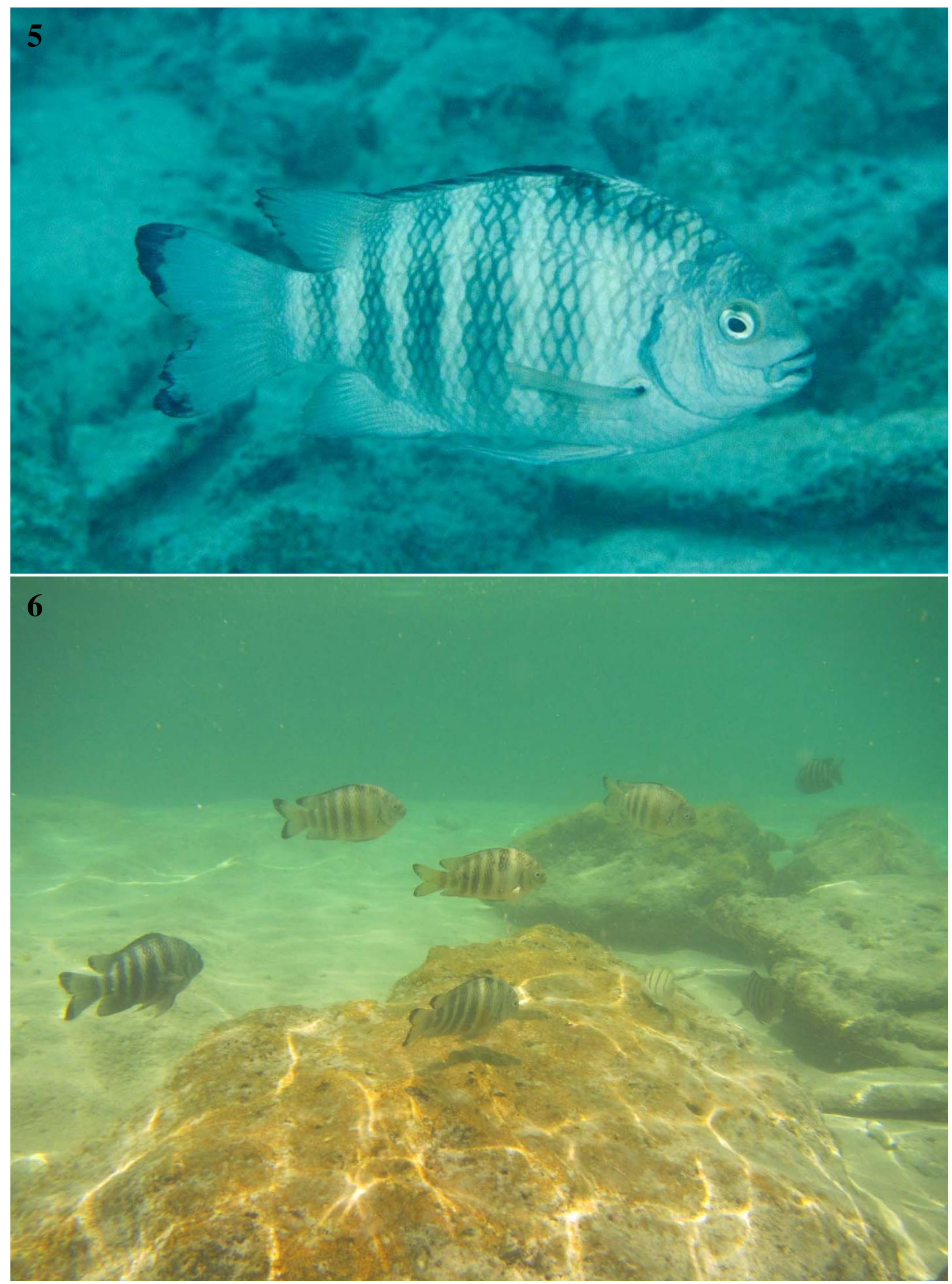

Plates 5 and 6. Abudefduf septemfasciatus with unusual black edging to second dorsal and caudal fins. Photos copyright of the author. 


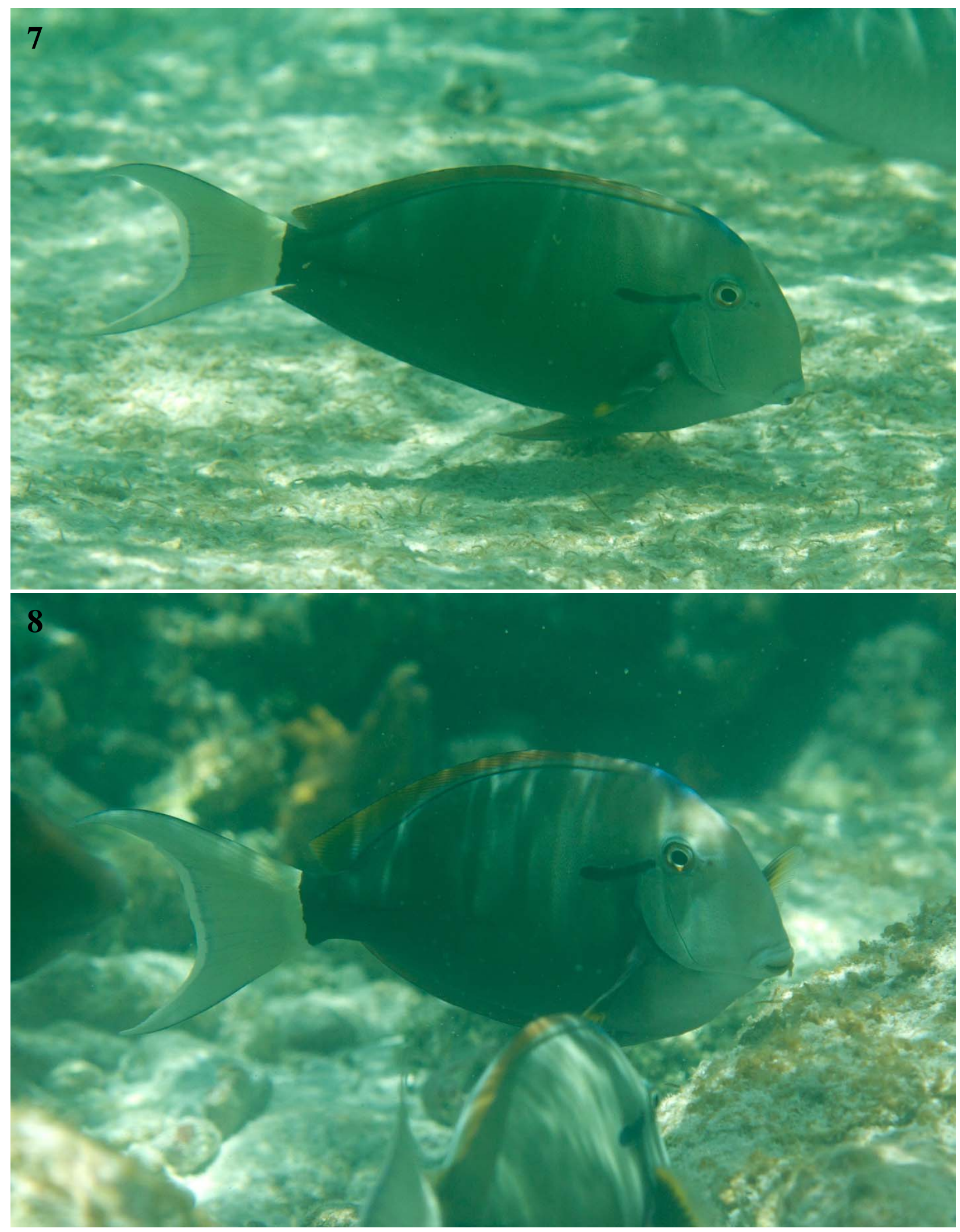

Plates 7 and 8. Unusual tail coloration in Acanthurus nigricauda. Photos copyright of the author. 


\section{APPENDIX A: THE SITES}

\section{Site 1: Lagoon, Motuhaga motu (Figure A1)}

After entering the water the author swam southeast 150-200 meters following the beach and reef. Maximum depth here was about five meters. The beach and shoreline were composed of broken coral rubble, but the lagoon bed was sandy away from shore. Some human rubbish (mainly plastic, wood, and metal) in the shallows close to shore. Visibility up to eight meters. Almost no corals seen. Visited twice, on 23 August 2012 and 24 August 2012 for a total of 174 minutes.

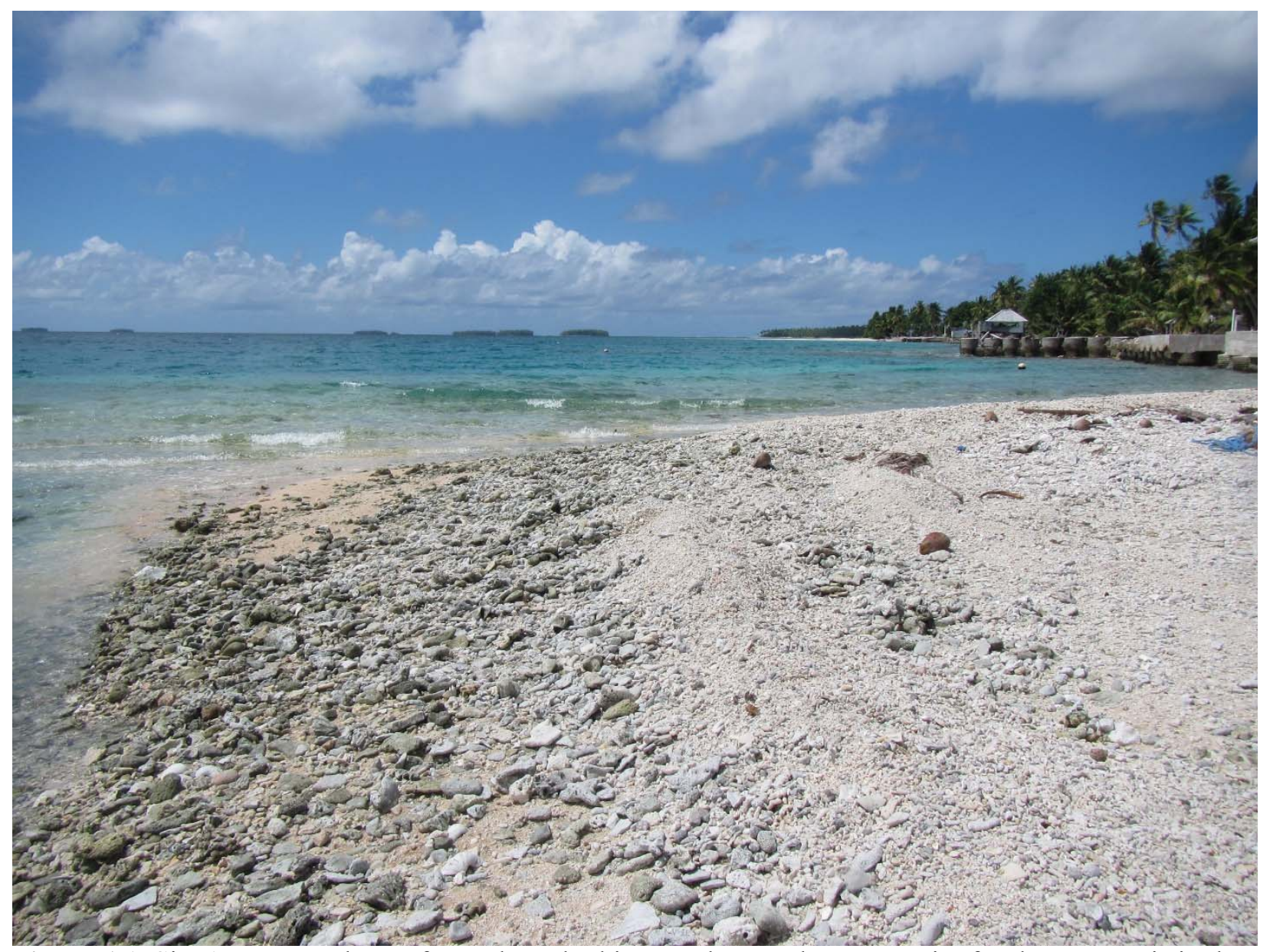

Figure A1. Site 1: Lagoon shore of Motuhaga looking southeast. The entry point for the surveys is in the foreground. Common families at this location were Holocentrids, Mullids, Labrids and Acanthurids. Photo copyright of the author. 


\section{Site 2: Channel between lagoon (Site 1) and reef flat (Site 3) (Figure A2)}

This channel, approximately 300 meters long, separates Vao and Motuhaga islets and is spanned by a concrete bridge. Maximum depth is one meter in a pool at the reef flat end, less than one meter elsewhere. During spring tides and storm surges the channel swells with water from the lagoon and covers a larger area before draining onto the reef flat. This site was frequently visited on foot due to its proximity to the author's accommodation but was rarely snorkelled because of its shallow depth.

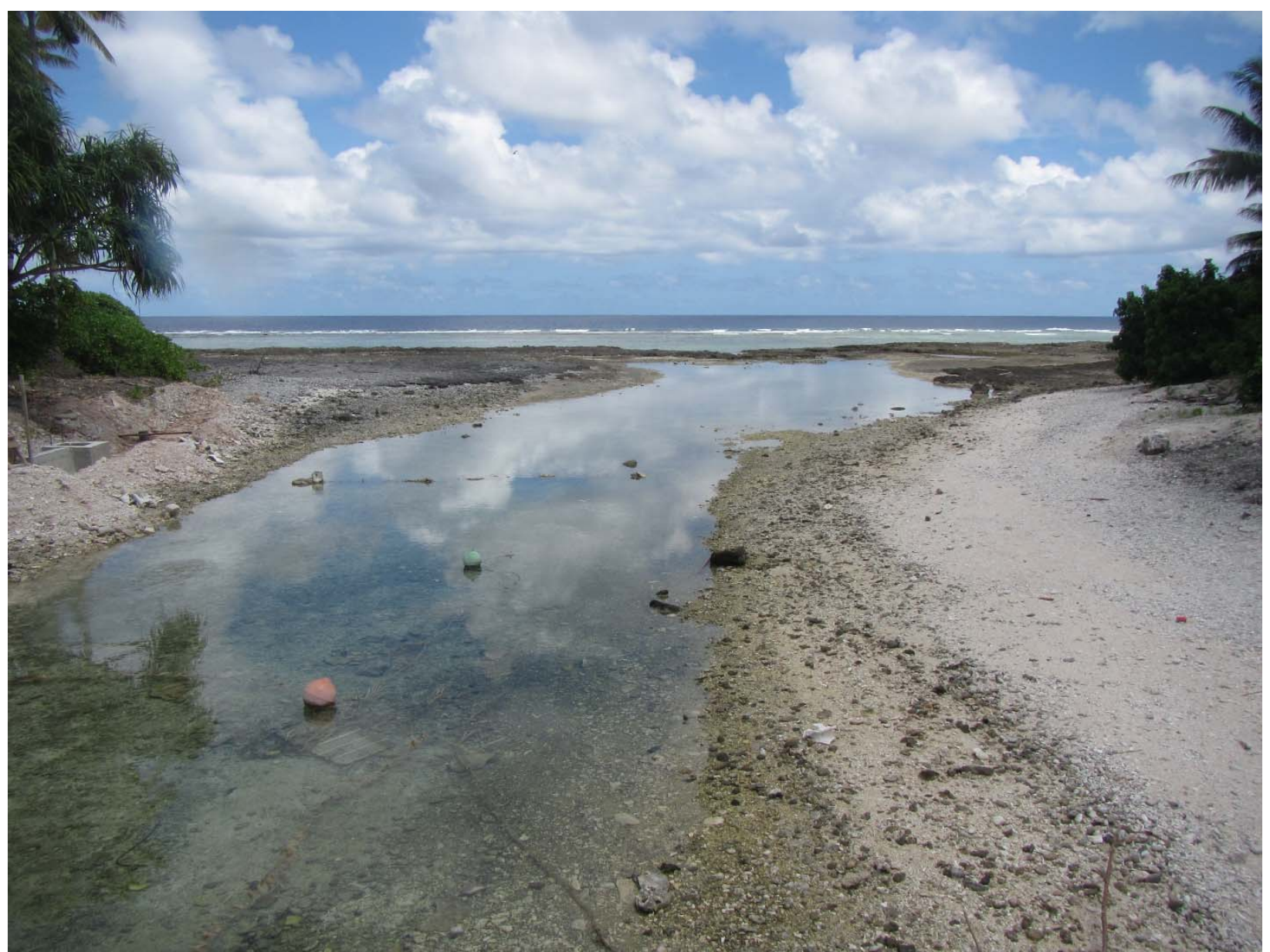

Figure A2. Site 2: Channel between Motuhaga (left) and Vao (right), looking towards the ocean. Only seven species were sighted here: Gymnothorax pictus; juvenile Abudefduf septemfasciatus and A. sordidus; Chrysiptera glauca; Halichoeres trimaculatus; Acanthurus triostegus; and a juvenile Arothron nigropunctatus. Most of these were seen around the spring tide when the channel and neighboring pools were full. Photo copyright of the author.

\section{Site 3: Reef flat (Figures A3 and A4)}

The reef flat on Motuhaga is around 500 meters in length and about 150 meters wide (to the edge of the reef). The reef was walked, and several pools on the reef flat were visited at both high and low tide. At low tide most of the flat is still under water, varying in depth from a few centimeters to $\sim 0.75$ meters in the pools. A sandy substrate and lots of corals. Visibility up to seven meters. Visited 23 August 2012, 24 August 2012, 30 August 2012, 4 September 2012, and twice on 5 September 2012 for a total of 531 minutes. 


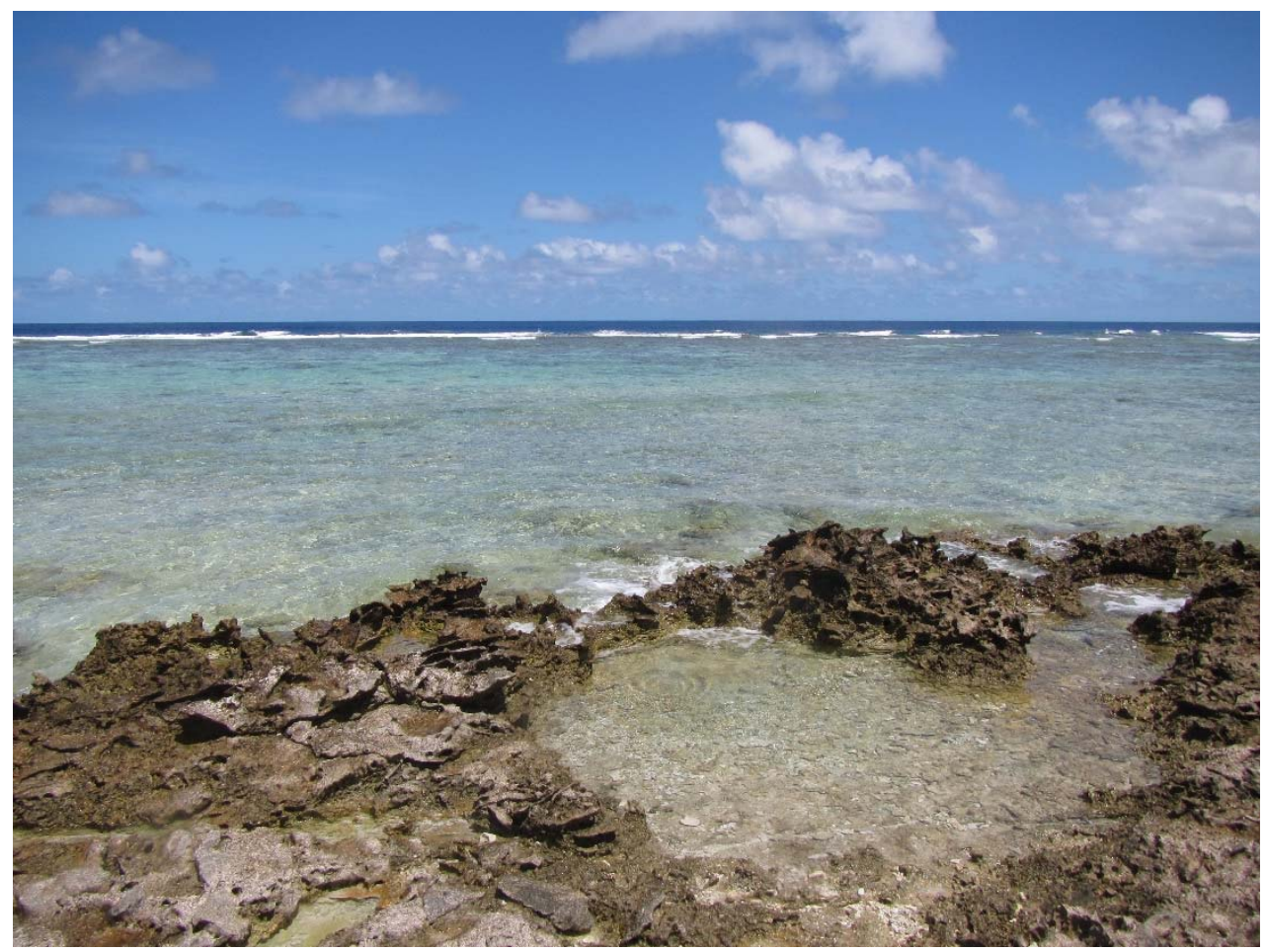

Figure A3. Site 3: Reef flat by Motuhaga at high tide. The Conglomerate Platform is in the immediate foreground. The platform appeared popular with Gymnothorax pictus, and in a short walk one afternoon seven were seen, including two juveniles and an adult half out of the water chasing a crab. Photo copyright of the author.

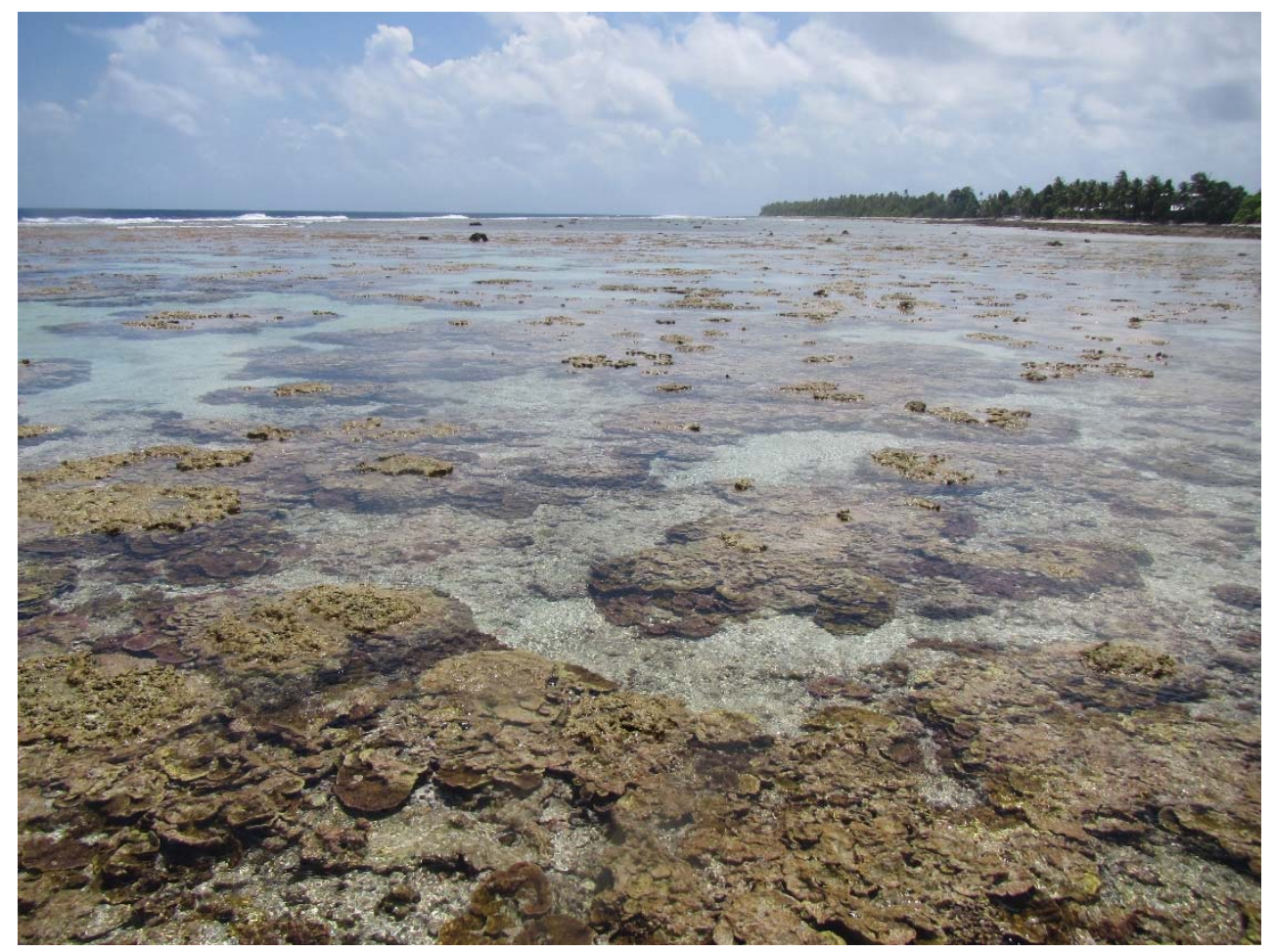

Figure A4. Site 3: Reef flat on Motuhaga at low tide, looking northwards. The island on the right is Vao. Sixty-six species were seen here, plus the hybrid acanthurid. Chaetodontids, Labrids and Acanthurids were the most speciose families. Photo copyright of the author. 


\section{Site 4: Wharf and channel (Figure A5)}

A manmade channel in the reef flat for the barge to ferry passengers and cargo from the wharf to the cargo ship. GPS coordinates are taken from the wharf. Snorkelled the channel itself and the reef flat either side. The channel acts as a drainage for the reef flat, and water breaking onto the flats runs into the channel and then out to the ocean. As a result, there are very strong outward currents toward the mouth of the channel, particularly within the channel itself. Consequently, that end of the channel was not snorkelled. Substrate was mainly rock with some sand, and corals on the reef flat. Visibility up to seven meters, but variable due to the amount of sand and sediment that is washed into the channel. Probably as a result of all this sediment, this site had the highest density of fishes with large numbers of fistularids, scarids, and acanthurids seen. Maximum depth up to four meters. Visited 23 August 2012 and 27 August 2012 for a total of 101 minutes.

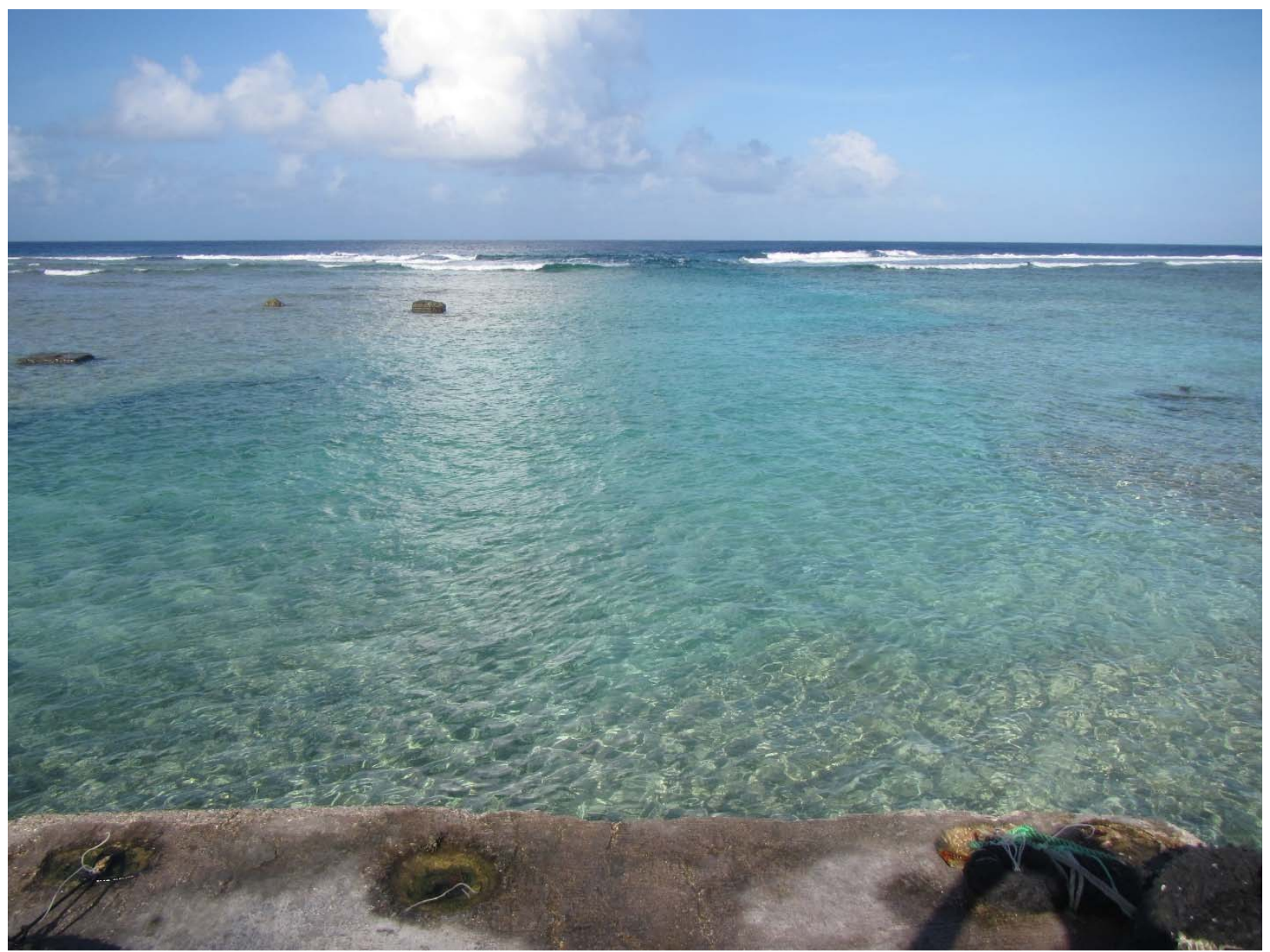

Figure A5. Site 4: The channel in front of the wharf (foreground) at high tide. Photo copyright of the author. 


\section{Site 5: Lagoon, Te Fakanava motu (Figure A6)}

Swam into lagoon approximately 100 meters from shore. Maximum depth seen was around eight meters. The substrate was sand, but numerous pinnacles reaching from lagoon bottom to less than $\sim 0.5$ meters below the surface. Some corals growing close to surface. Visibility around 15-20 meters at surface, 10 meters or less at bottom, and much reduced in shallower waters. Visited once on 25 August 2012 for 185 minutes.

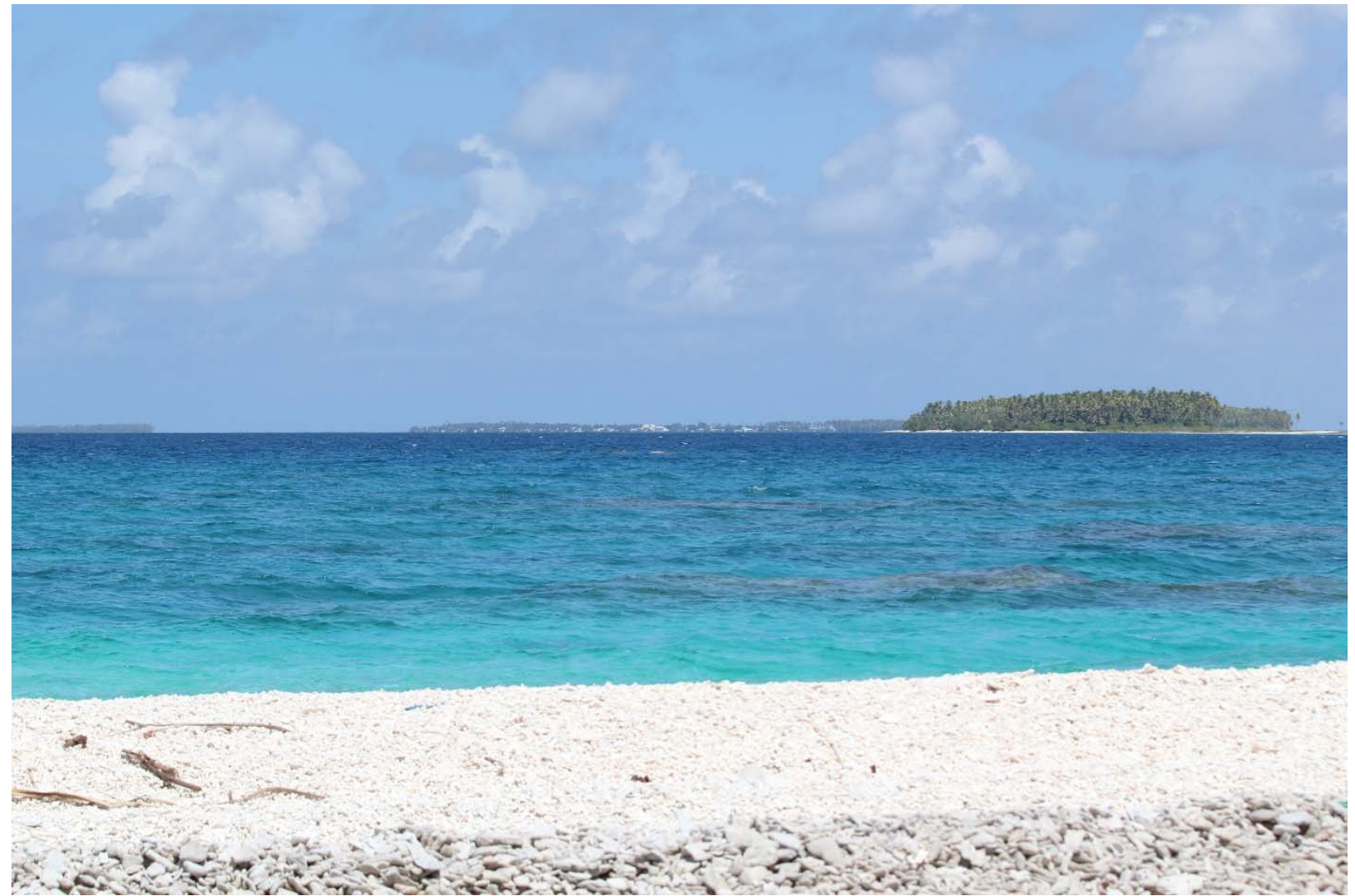

Figure A6. Site 5: Lagoon at Te Fakanava Motu, looking south toward Nukunonu Village (center frame) approximately eight kilometers away. Several large pinnacles occur as close as 30 meters from shore, and are the focal points for most of the 71 species recorded here. The hybrid acanthurid was also seen here. Photo copyright of the author. 


\section{Site 6: Lagoon, Vao motu (Figure A7)}

Entered the water from a boat launching site on the southeast side of the government building and swam along the reef 50-75 meters into the lagoon, and southeast along the shore for 20 meters. The lagoon bed was sandy, rock around the seawall and shoreline. A reef extends from the shore straight out into the lagoon for several hundred meters. Maximum depth around 5-6 meters in the area surveyed; very few corals on reef. Visited 28 August 2012 for a total of 90 minutes; session finished early after a facial encounter with a stinging jellyfish.

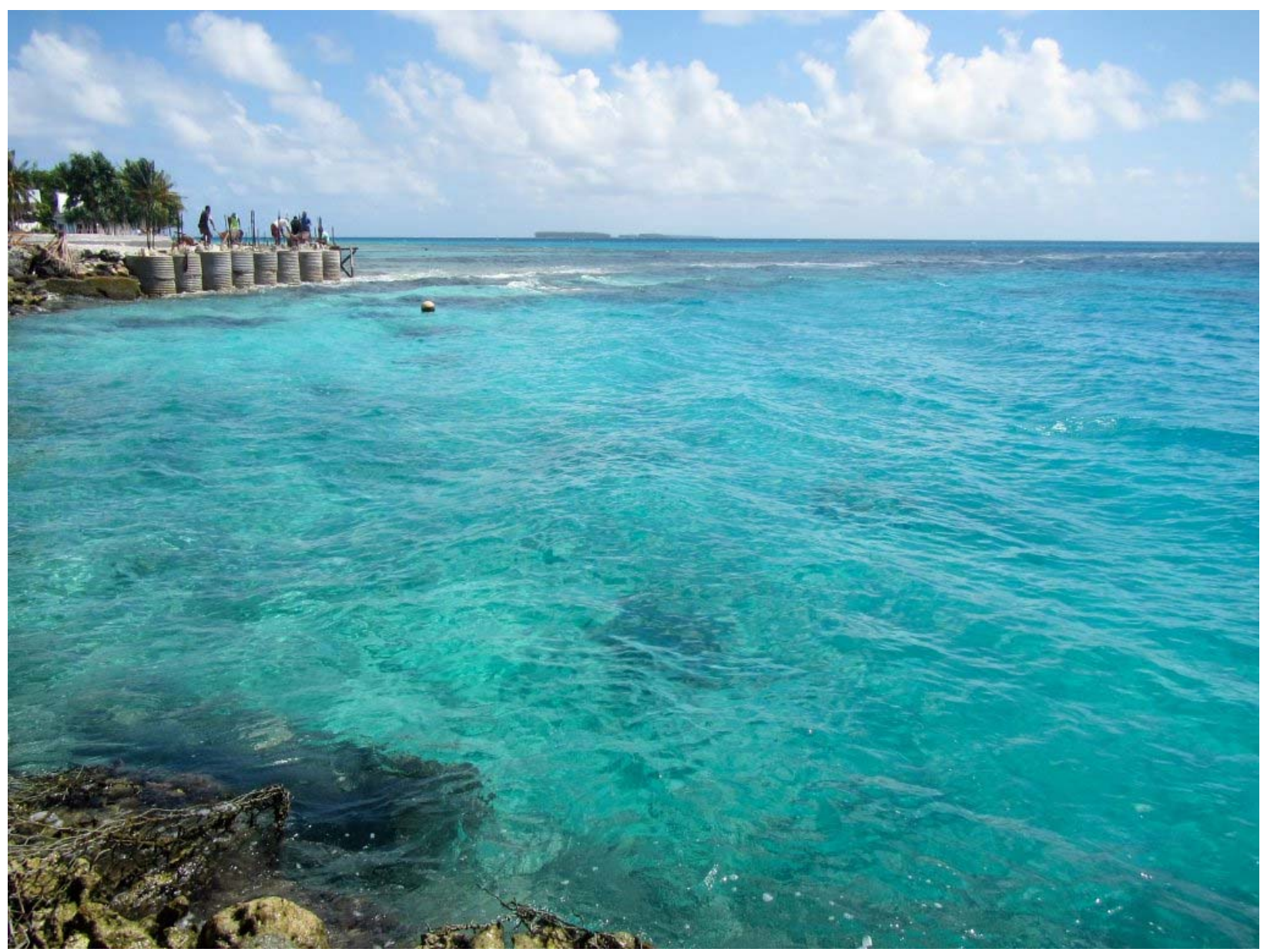

Figure A7. Site 6: Lagoon next to Vao motu, looking north. The structure on the left is a seawall next to the government building, built on a reef that extends out into the lagoon. Forty species were sighted here. Photo copyright of the author. 


\section{Site 7: Reef (Figure A8)}

From there I swam over the reef approximately 50 meters in each direction. The edge of the reef flat drops around 4.5 meters to the fore-reef, which then slopes down for 50 meters to a depth of about eight meters before ending in a vertical drop-off. The reef crest where the waves break is mostly bare rock with spurs and grooves, but the fore-reef has extensive coral cover, mostly hard corals. Visibility $30+$ meters. Visited on 2 September 2012, 3 September 2012, and 6 September 2012, for a total of 143 minutes.

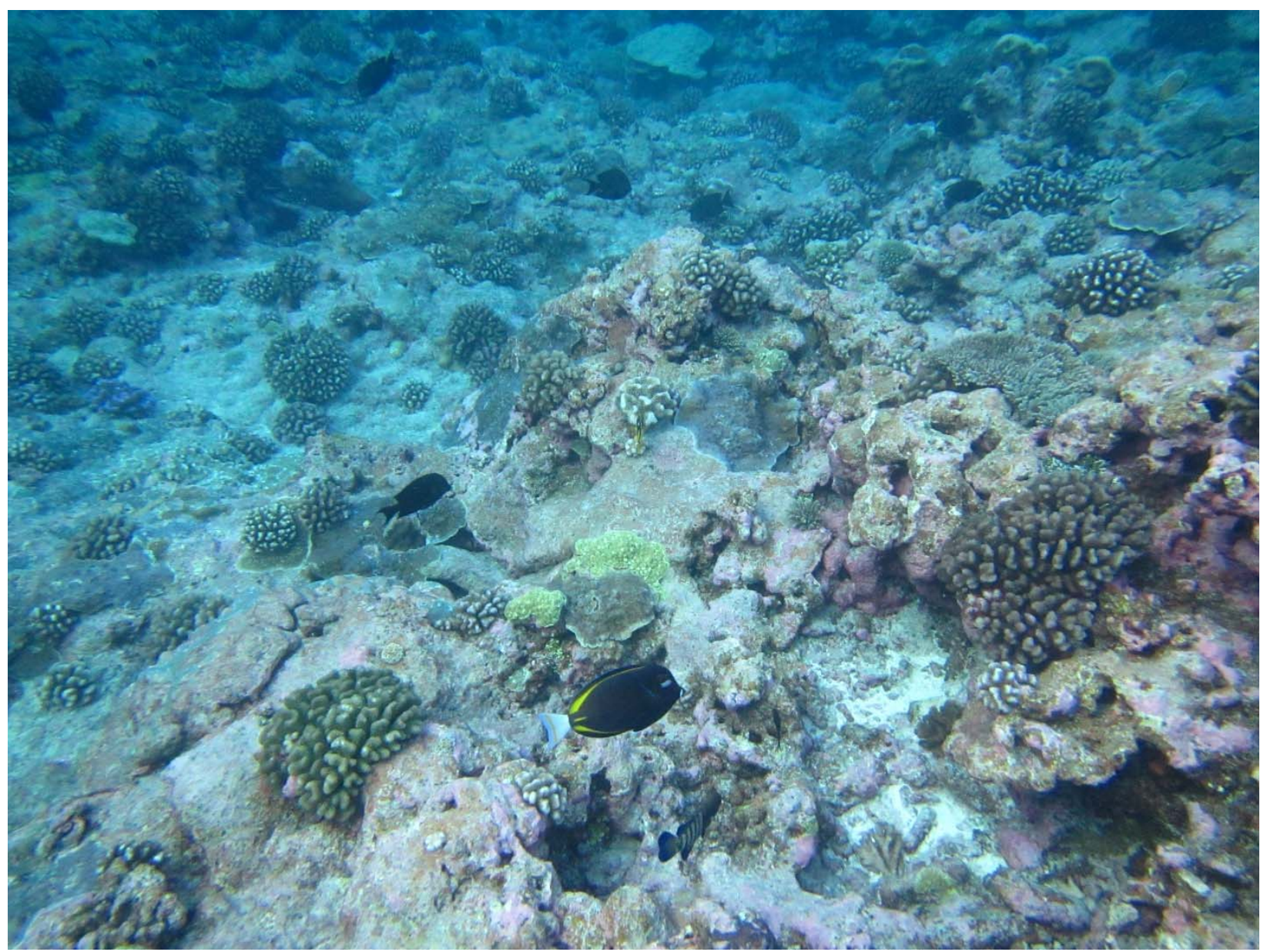

Figure A8. Site 7: The fore-reef next to Motuhaga. A total of 85 species were recorded, including the hybrid acanthurid, and several families were represented at this site only: Aulostomidae, Echeneidae, Kyphosidae, Cirrhitidae, and Sphyraenidae. Photo copyright of the author. 


\section{APPENDIX B: CHECKLIST OF THE FISHES OF TOKELAU}

The following checklist is compiled from Table 2 of this paper, from 239 lots in the collection of the National Museum of Natural History (NMNH), 76 lots from the Academy of Natural Sciences in Philadelphia (ANS), 9 specimens from the Natural History Museum in London (BNHM), 2 lots from the California Academy of Sciences (CAS), and from selected publications where species have been reliably identified (van Pel, 1959; Tuna Program, 1983; Gillett, 1985; Gillett, 1990; Passfield, 1998). Records from collections identified to genus or family level only may represent multiple lots and more than one species. Records from this paper and other written references that are not identified to species level have been omitted.

A total of 230 species and 53 families are listed, with a further 20 records from collections identified to genus only, and 4 identified to family level only. The families with the most species are Labridae with 25 species, Pomacentridae with 16, Chaetodontidae with 15, Acanthuridae with 15, Carangidae with 11, and the Muraenidae, Serranidae, and Scaridae with 10 each. The most speciose genera are Chaetodon with 11 species, Acanthurus with 10 species, Gymnothorax with 8 species, and Epinephalus with 7 species.

Species are listed phylogenetically by family; genus and species are then listed alphabetically. Family classification follows Nelson (2006). Atolls where each species were reported or collected are listed where known. Superscipt numbers indicate the reference as follows:

${ }^{1}$ Visual census in this work

${ }^{2}$ Specimens in the NMNH collection

${ }^{3}$ Specimens in the ANS collection

${ }^{4}$ Specimens in the CAS collection

${ }^{5}$ Specimens in the BNMH collection

${ }^{6}$ van Pel (1959)

${ }^{7}$ Tuna Programme (1983)

${ }^{8}$ Gillett (1985)

${ }^{9}$ Gillett (1990)

${ }^{10}$ Passfield (1998)

\section{Carcharhinidae}

Carcharhinus melanopterus ${ }^{1}$ (Quoy and Gaimard, 1824) - Nukunonu

\section{Myliobatidae}

Aetobatus narinari ${ }^{1}$ (Euphrasen, 1790) - Nukunonu

\section{Moringuidae}

Moringua sp. ${ }^{3}$ - Nukunonu, Fakaofo

\section{Chlopsidae}

Kaupichthys brachychirus ${ }^{3}$ Schultz in Schultz, Herald, Lachner, Welander and Woods, 1953 -

Fakaofo

\section{Muraenidae}

Anarchias allardicei ${ }^{3}$ Jordan and Starks in Jordan and Seale, 1906 - Fakaofo

Echidna nebulosa ${ }^{1}$ (Ahl, 1789) - Nukunonu

Gymnothorax sp. ${ }^{3}-$ Nukunonu, Fakaofo

Gymnothorax buroensis ${ }^{3}$ (Bleeker, 1857) - Nukunonu, Fakaofo

Gymnothorax flavimarginatus ${ }^{3}$ (Rüppell, 1830) - Atafu, Fakaofo

Gymnothorax gracilicauda ${ }^{3}$ Jenkins, 1903 - Nukunonu

Gymnothorax javanicus $^{1,3}$ (Bleeker, 1859) - Nukunonu, Fakaofo 
Gymnothorax margaritophorus ${ }^{3}$ Bleeker, 1865 - Fakaofo

Gymnothorax meleagris ${ }^{3}$ (Shaw in Shaw and Nodder, 1795) - Nukunonu

Gymnothorax pictus ${ }^{1,3}$ (Ahl, 1789) - Atafu, Nukunonu

Gymnothorax rueppellii ${ }^{3}$ (McClelland, 1844) - Fakaofo

\section{Ophichthyidae}

Brachysomophis crocodilinus ${ }^{3}$ (Bennett, 1833) - Fakaofo

Callechelys catostoma ${ }^{3}$ (Schneider and Forster in Bloch and Schneider, 1801) - Fakaofo

Leiuranus semicinctus ${ }^{3}$ (Lay and Bennett, 1839) - Atafu, Fakaofo

Muraenichthys sp. ${ }^{3}$ - Fakaofo

\section{Congridae}

Conger cinereus ${ }^{3}$ Rüppell, 1830 - Fakaofo

\section{Engraulidae}

Encrasicholina punctifer ${ }^{8}$ Fowler, 1938 - Fakaofo

\section{Clupeidae}

Spratelloides delicatulus ${ }^{7,8}$ (Bennett, 1832) - Fakaofo

\section{Chanidae}

Chanos $\operatorname{chanos}^{6}$ (Forsskål, 1775) - Atafu, Fakaofo

\section{Synodontidae}

Saurida gracilis ${ }^{2}$ (Quoy and Gaimard, 1824) - Atafu, Nukunonu, Fakaofo

Synodus variegatus ${ }^{2}$ (Lacepède, 1803) - Fakaofo

\section{Bythitidae}

Dinematichthys sp. ${ }^{2}$ - Fakaofo

\section{Mugilidae}

Crenimugil crenilabris ${ }^{1}$ (Forsskål, 1775) - Nukunonu

Liza vaigiensis $^{7}$ (Quoy and Gaimard, 1825)

Neomyxus leuciscus ${ }^{1,3}$ (Günther, 1872) - Nukunonu

Valamugil seheli ${ }^{7}$ (Forsskål, 1775)

\section{Exocoetidae}

Cheilopogon antoncichi ${ }^{2}$ (Woods and Schultz in Schultz et al., 1953)

Cheilopogon atrisignis ${ }^{2}$ (Jenkins, 1903)

Cheilopogon spilonotopterus $^{2}$ (Bleeker, 1866)

Cypselurus angusticeps ${ }^{2}$ Nichols and Breder, 1935

\section{Hemiramphidae}

Hyporhamphus acutus $^{2}$ (Günther, 1872) - Atafu, Nukunonu, Fakaofo

Hyporhamphus affinis ${ }^{3}$ (Günther, 1866) - Nukunonu

\section{Belonidae}

Platybelone argalus $^{2}$ (Lesueur, 1821) - Atafu, Nukunonu, Fakaofo

\section{Holocentridae}

Myripristis amaena ${ }^{2}$ (Castelnau, 1873) - Fakaofo

Myripristis violacea ${ }^{1,2}$ Bleeker, 1851 - Nukunonu, Fakaofo

Neoniphon opercularis ${ }^{1,2}$ (Valenciennes in Cuvier and Valenciennes, 1831) - Nukunonu

Neoniphon samara ${ }^{1,2}$ (Forsskål, 1775) - Atafu, Nukunonu

Sargocentron caudimaculatum ${ }^{1}$ (Rüppell, 1838) - Nukunonu

Sargocentron ittodai ${ }^{2}$ (Jordan and Fowler, 1902) - Fakaofo

Sargocentron microstoma ${ }^{1,2}$ (Günther, 1859) - Atafu, Nukunonu 
Sargocentron punctatissimum ${ }^{2,3}$ (Cuvier in Cuvier and Valenciennes, 1829) - Atafu, Nukunonu Sargocentron spiniferum ${ }^{1,2}$ (Forsskål, 1775) - Nukunonu

\section{Aulostomidae}

Aulostomus chinensis ${ }^{1}$ (Linnaeus, 1766) - Nukunonu

\section{Fistulariidae}

Fistularia commersonii ${ }^{1,2}$ Rüppell, 1838 - Nukunonu, Fakaofo

\section{Scorpaenidae}

Pterois radiata $^{3}$ (Cuvier in Cuvier and Valenciennes, 1829) - Nukunonu

Scorpaenodes scaber ${ }^{2}$ (Ramsay and Ogilby, 1886) - Atafu, Fakaofo

Scorpaenopsis sp. ${ }^{2}$ - Fakaofo

\section{Serranidae}

Cephalopholis argus ${ }^{1,2,3}$ Block and Schneider, 1801 - Atafu, Nukunonu, Fakaofo

Cephalopholis leopardus ${ }^{2,3}$ (Lacepède, 1801) - Atafu, Fakaofo

Cephalopholis urodeta ${ }^{1}$ (Forster in Bloch and Schneider, 1801) - Nukunonu

Epinephelus sp. ${ }^{3}-$ Fakaofo

Epinephelus fuscoguttatus ${ }^{1}$ (Forsskål, 1775) - Nukunonu

Epinephelus hexagonatus ${ }^{1,2}$ (Forster in Bloch and Schneider, 1801) - Nukunonu, Fakaofo

Epinephelus melanostigma ${ }^{3}$ (Schultz in Schultz et al., 1953) - Nukunonu

Epinephelus merra ${ }^{1,3}$ Bloch 1793 - Nukunonu, Fakaofo

Epinephelus polyphekadion ${ }^{1,2}$ (Bleeker 1849) - Nukunonu, Fakaofo

Epinephelus socialis ${ }^{3}$ (Günther, 1873) - Nukunonu

Epinephelus tauvina ${ }^{3}$ (Forsskål, 1775) - Nukunonu

\section{Plesiopidae}

Plesiops corallicola ${ }^{2,3}$ Bleeker 1853 - Atafu, Nukunonu

\section{Apogonidae}

Apogon coccineus ${ }^{2}$ Rüppell, 1838 - Atafu

Apogonichthys ocellatus ${ }^{2}$ (Weber, 1913) - Fakaofo

Cheilodipterus macrodon ${ }^{2}$ (Lacepède, 1802) - Fakaofo

Cheilodipterus quinquelineatus ${ }^{2}$ (Cuvier in Cuvier and Valenciennes, 1828) - Fakaofo

Fowleria sp. ${ }^{2}$ - Atafu, Fakaofo

Nectamia fusca ${ }^{2}$ (Quoy and Gaimard, 1825) - Atafu, Fakaofo

Ostorhinchus novemfasciatus ${ }^{2}$ (Cuvier in Cuvier and Valenciennes, 1828) - Atafu, Fakaofo

Ostorhinchus taeniophorus ${ }^{2}$ (Regan, 1908) - Fakaofo

Pristiapogon exostigma ${ }^{2}$ (Jordan and Starks, 1906) - Atafu, Nukunonu, Fakaofo

Pristiapogon kallopterus ${ }^{2}$ (Bleeker, 1856) - Nukunonu

\section{Coryphaenidae}

Coryphaena hippurrus ${ }^{8}$ Linnaeus, 1758 - Fakaofo

\section{Echeneidae}

Echeneis naucrates ${ }^{1}$ Linneaus, 1758 - Nukunonu

\section{Carangidae}

Carangoides ferdau ${ }^{2}$ (Forsskål, 1775) - Nukunonu

Caranx melampygus ${ }^{1,3,5}$ Cuvier in Cuvier and Valenciennes, 1833 - Atafu, Nukunonu

Caranx sexfasciatus ${ }^{1,10}$ Quoy and Gaimard, 1825 - Nukunonu, Fakaofo

Decapterus macrosoma ${ }^{8}$ Bleeker, 1851 - Fakaofo

Decapterus russelli ${ }^{6}$ (Rüppell, 1830) - Atafu 
Elagatis bipinnulata ${ }^{7,8}$ (Quoy and Gaimard, 1825) - Fakaofo

Naucrates ductor ${ }^{6}$ (Linnaeus, 1758) - Atafu

Selar crumenophthalmus ${ }^{6,8}$ (Bloch, 1793) - Atafu, Fakaofo

Trachinotus baillonii ${ }^{1}$ (Lacepède, 1801) - Nukunonu

Trachinotus blochii ${ }^{6}$ (Lacepède, 1801) - Atafu

Trachinotus botla ${ }^{6}$ (Shaw, 1803) - Atafu, Fakaofo

\section{Lutjanidae}

Aphareus furca ${ }^{1}$ (Lacepède, 1801) - Nukunonu

Aprion virescens ${ }^{1}$ Valenciennes in Cuvier and Valenciennes, 1830 - Nukunonu

Lutjanus bohar ${ }^{1}$ (Forsskål, 1775) - Nukunonu

Lutjanus ehrenbergii ${ }^{4}$ (Peters, 1869)

Lutjanus fulvus ${ }^{1}$ (Forster in Bloch and Schneider, 1801) - Nukunonu

Lutjanus gibbus ${ }^{1}$ (Forsskål, 1775) - Nukunonu

Lujanus monostigma ${ }^{1}$ (Cuvier in Cuvier and Valenciennes, 1828) - Nukunonu

\section{Lethrinidae}

Gnathodentex aureolineatus ${ }^{1}$ (Lacepède, 1802) - Nukunonu

Lethrinus xanthochilus ${ }^{1}$ Klunzinger 1870 - Nukunonu

Monotaxis grandoculis ${ }^{1}$ (Forsskål, 1775) - Nukunonu

\section{Mullidae}

Mulloidichthys sp. ${ }^{2}-$ Atafu, Fakaofo

Mulloidichthys flavolineatus ${ }^{1,2}$ (Lacepède, 1801) - Atafu, Nukunonu, Fakaofo

Mulloidichthys vanicolensis ${ }^{1,4}$ (Valenciennes in Cuvier and Valenciennes, 1831) - Nukunonu

Parupeneus barberinus ${ }^{1,2}$ (Lacepède, 1801) - Atafu, Nukunonu

Parupeneus crassilabris ${ }^{2}$ (Valenciennes in Cuvier and Valenciennes, 1831) - Nukunonu, Fakaofo

Parupeneus cyclostomus ${ }^{1,2}$ (Lacepède, 1801) - Nukunonu, Fakaofo

Parupeneus insularis ${ }^{1}$ (Randall and Myers, 2002) - Nukunonu

Parupeneus multifasciatus ${ }^{1,5}$ (Quoy and Gaimard, 1825) - Nukunonu

\section{Kyphosidae}

Kyphosus cinerascens ${ }^{8}$ (Forsskål, 1775) - Fakaofo

Kyphosus vaigiensis ${ }^{1}$ (Quoy and Gaimard, 1825) - Nukunonu

\section{Chaetodontidae}

Chaetodon auriga ${ }^{1,2}$ Forsskål, 1775 - Atafu, Nukunonu, Fakaofo

Chaetodon citrinellus ${ }^{1,2}$ Cuvier in Cuvier and Valenciennes, 1831 - Atafu, Nukunonu

Chaetodon ephippium ${ }^{1}$ Cuvier in Cuvier and Valenciennes, 1831- Nukunonu

Chaetodon lunula ${ }^{1,3}$ (Lacepède, 1802) - Nukunonu

Chaetodon lunulatus ${ }^{1,2}$ Quoy and Gaimard, 1825 - Nukunonu, Fakaofo

Chaetodon ornatissimus ${ }^{1}$ Cuvier in Cuvier and Valenciennes, $1831-$ Nukunonu

Chaetodon quadrimaculatus ${ }^{1,2}$ Gray, 1831 - Atafu, Nukunonu

Chaetodon reticulatus ${ }^{1}$ Cuvier in Cuvier and Valenciennes, 1831 - Nukunonu

Chaetodon semeion ${ }^{1,2}$ Bleeker, 1855 - Atafu, Nukunonu, Fakaofo

Chaetodon ulietensis ${ }^{1,2}$ Cuvier in Cuvier and Valenciennes, 1831- Atafu, Nukunonu, Fakaofo

Chaetodon vagabundus ${ }^{1}$ Linneaus, 1758 - Nukunonu

Forcipiger flavissimus ${ }^{1}$ Jordan and McGregor in Jordan and Evermann, 1898 - Nukunonu

Forcipiger longirostris $^{1}$ (Broussonet, 1782) - Nukunonu

Heniochus chrysostomus ${ }^{1}$ Cuvier in Cuvier and Valenciennes, 1831 - Nukunonu 
Heniochus monoceros ${ }^{1}$ Cuvier in Cuvier and Valenciennes, 1831 - Nukunonu

\section{Pomacanthidae}

Centropyge flavissima ${ }^{1,10}$ (Cuvier in Cuvier and Valenciennes, 1831) - Nukunonu, Fakofo

Pygoplites diacanthus ${ }^{1}$ (Boddaert, 1772) - Nukunonu

\section{Kuhlidae}

Kuhlia mugil ${ }^{1}$ (Forster in Bloch and Schneider, 1801) - Nukunonu

\section{Cirrhitidae}

Neocirrhites armatus ${ }^{1}$ Castelnau, 1873 - Nukunonu

Paracirrhites arcatus ${ }^{1,2}$ (Cuvier in Cuvier and Valenciennes, 1829) - Nukunonu

Paracirrhites hemistictus ${ }^{1,2}$ (Günther, 1874) - Nukunonu

\section{Pomacentridae}

Pomacentridae $^{2}$ - Atafu, Nukunonu

Abudefduf septemfasciatus ${ }^{1,2,3}$ (Cuvier in C and V, 1830) - Atafu, Nukunonu, Fakaofo

Abudefduf sordidus ${ }^{1,2}$ (Forsskål, 1775) - Atafu, Nukunonu, Fakaofo

Chromis sp. ${ }^{2}$ - Nukunonu

Chromis acare $^{1}$ Randall and Swerdloff, 1973 - Nukunonu

Chromis margaritifer ${ }^{1}$ Fowler, 1946 - Nukunonu

Chromis viridis $^{2}$ (Cuvier in Cuvier and Valenciennes, 1830) - Atafu, Nukunonu, Fakaofo

Chromis xanthura ${ }^{1}$ (Bleeker, 1854) - Nukunonu

Chrysiptera sp. ${ }^{2}-$ Nukunonu

Chrysiptera glauca ${ }^{1,2,3}$ (Cuvier in Cuvier and Valenciennes, 1830) - Atafu, Nukunonu, Fakaofo

Dascyllus aruanus ${ }^{1,2}$ (Linneaus, 1758) - Atafu, Nukunonu, Fakaofo

Lepidozygus tapeinosoma ${ }^{9}$ (Bleeker, 1856) - Fakaofo

Plectroglyphidodon dickii ${ }^{1}$ (Liénard, 1839) - Nukunonu

Plectroglyphidodon imparipennis ${ }^{2}$ (Vaillant and Sauvage, 1875) - Atafu

Pomacentrus coelestis ${ }^{2,5}$ Jordan and Starks, 1901 - Fakaofo

Pomacentrus pavo ${ }^{1,2}$ (Bloch, 1787) - Atafu, Nukunonu, Fakaofo

Pomacentrus vaiuli ${ }^{1,2}$ Jordan and Seale, 1906 - Atafu, Nukunonu, Fakaofo

Stegastes sp. ${ }^{2}$ - Fakaofo

Stegastes albifasciatus ${ }^{1,2,3}$ (Schlegel and Müller, 1839) - Nukunonu, Fakaofo

Stegastes nigricans ${ }^{1,3}$ (Lacepède, 1802) - Nukunonu

\section{Labridae}

Anampses caeruleopunctatus ${ }^{1}$ Rüppell, 1829 - Nukunonu

Cheilinus fasciatus ${ }^{1,2,3}$ (Bloch, 1791) - Nukunonu, Fakaofo

Cheilinus trilobatus ${ }^{1,2}$ Lacepède, 1801 - Atafu, Nukunonu

Cheilinus undulatus ${ }^{1}$ Rüppell, 1835 - Nukunonu

Coris aygula ${ }^{1}$ Lacepède, 1801 - Nukunonu

Coris gaimard $^{1}$ (Quoy and Gaimard, 1824) - Nukunonu

Epibulus insidiator ${ }^{1,2,3}$ (Pallas, 1770) - Atafu, Nukunonu, Fakaofo

Gomphosus varius ${ }^{1,2,3}$ Lacepède, 1801 - Nukunonu, Fakaofo

Halichoeres sp. ${ }^{2}-$ Fakaofo

Halichoeres hortulanus $^{1,2}$ (Lacepède, 1801) - Nukunonu

Halichoeres margaritaceus ${ }^{1,2}$ (Valenciennes in $\mathrm{C}$ and V, 1839) - Atafu, Nukunonu, Fakaofo

Halichoeres trimaculatus ${ }^{1,2,3}$ (Quoy and Gaimard, 1834) - Atafu, Nukunonu, Fakaofo

Hemigymnus fasciatus ${ }^{1}$ (Bloch, 1792) - Nukunonu 
Labroides bicolor ${ }^{1,2}$ Fowler and Bean, 1928 - Nukunonu

Labroides dimidiatus $^{1,2}$ (Valenciennes in Cuvier and Valenciennes, 1839) - Nukunonu, Fakaofo

Labroides rubrolabiatus ${ }^{1}$ Randall, 1958 - Nukunonu

Novaculichthys taeniourus ${ }^{2}$ (Lacepède, 1801) - Atafu

Oxycheilinus digramma ${ }^{3}$ (Lacepède, 1801) - Fakaofo

Oxycheilinus unifasciatus ${ }^{1}$ (Streets, 1877) - Nukunonu

Pseudocheilinus hexataenia ${ }^{2}$ (Bleeker, 1857) - Fakaofo

Pseudocheilinus tetrataenia ${ }^{3}$ - Fakaofo

Stethojulis bandanensis ${ }^{1,2}$ (Bleeker, 1851) - Atafu, Nukunonu, Fakaofo

Thalassoma amblycephalum ${ }^{1}$ (Bleeker, 1856) - Nukunonu

Thalassoma hardwicke ${ }^{1,2}$ (Bennett, 1830) - Atafu, Nukunonu, Fakaofo

Thalassoma purpureum ${ }^{1,2,4}$ (Forsskål, 1775) - Atafu, Nukunonu, Fakaofo

Thalassoma quinquevittatum ${ }^{1,2}$ (Lay and Bennett, 1839) - Atafu, Nukunonu, Fakaofo

\section{Scaridae}

Scaridae $^{2}$ - Fakaofo

Cetoscarus ocellatus ${ }^{1}$ (Valenciennes in Cuvier and Valenciennes, 1840) - Nukunonu

Chlorurus frontalis ${ }^{1}$ (Valenciennes in Cuvier and Valenciennes, 1839) - Nukunonu

Chlorurus microrhinos ${ }^{1}$ (Bleeker, 1854) - Nukunonu

Chlorurus spilurus ${ }^{1,4}$ (Valenciennes in Cuvier and Valenciennes, 1840) - Nukunonu

Hipposcarus longiceps ${ }^{1}$ (Valenciennes in Cuvier and Valenciennes, 1839) - Nukunonu

Scarus altipinnis ${ }^{1}$ (Steindachner, 1879) - Nukunonu

Scarus frenatus ${ }^{1}$ Lacepède, 1802 - Nukunonu

Scarus psittacus ${ }^{1}$ Forsskål, 1775 - Nukunonu

Scarus rubroviolaceus ${ }^{1}$ Bleeker, 1847 - Nukunonu

Scarus schlegeli ${ }^{1}$ (Bleeker, 1861) - Nukunonu

\section{Pinguipedidae}

Parapercis millepunctata ${ }^{1,2}$ (Günther, 1860) - Atafu, Nukunonu

\section{Blenniidae}

Blenniella paula ${ }^{1,2}$ (Bryan and Herre, 1903) - Atafu, Nukunonu, Fakaofo

Cirripectes variolosus ${ }^{2}$ (Valenciennes in Cuvier and Valenciennes, 1836) - Nukunonu

Entomacrodus striatus ${ }^{2}$ (Valenciennes in Cuvier and Valenciennes, 1836) - Fakaofo

Istiblennius edentulus ${ }^{2,3}$ (Forster and Schneider in Bloch and Schneider, 1801) - Atafu, Nukunonu, Fakaofo

Istiblennius lineatus ${ }^{2}$ (Valenciennes in Cuvier and Valenciennes, 1836) - Atafu, Fakaofo

Plagiotremus tapeinosoma ${ }^{2}$ (Bleeker, 1857) - Nukunonu

Rhabdoblennius sp. ${ }^{2}-$ Fakaofo

\section{Eleotridae}

Eleotridae $^{2}$ - Atafu, Fakaofo

\section{Gobiidae}

Gobiidae $^{2}$ - Atafu

Amblygobius sp. ${ }^{2}$ - Fakaofo

Amblygobius phalaena ${ }^{2}$ (Valenciennes in Cuvier and Valenciennes, 1837) - Atafu

Asterropteryx sp. ${ }^{2}-$ Fakaofo

Asterropteryx semipunctata ${ }^{2}$ Rüppell, 1830 - Atafu

Ctenogobiops feroculus ${ }^{1}$ Lubbock and Polunin, 1977 - Nukunonu 
Gobiodon sp. ${ }^{2}-$ Fakaofo

Paragobiodon sp. ${ }^{2}$ - Fakaofo

Valenciennea sp. $^{2}$ - Fakaofo

Valenciennea sexguttata ${ }^{1}$ (Valenciennes in Cuvier and Valenciennes, 1837) - Nukunonu

Valenciennea strigata ${ }^{2}$ (Broussonet, 1782) - Atafu, Fakaofo

\section{Ptereleotridae}

Ptereleotris evides ${ }^{1}$ (Jordan and Hubbs, 1925) - Nukunonu

\section{Zanclidae}

Zanclus cornutus ${ }^{1,2,6}$ (Linneaus, 1758) - Atafu, Nukunonu, Fakaofo

\section{Acanthuridae}

Acanthurus sp. ${ }^{2}$ - Fakaofo

Acanthurus achilles ${ }^{1,4}$ Shaw, 1803 - Nukunonu

Acanthurus guttatus ${ }^{1}$ Forster in Bloch and Schneider, 1801 - Nukunonu

Acanthurus lineatus ${ }^{1}$ (Linneaus, 1758) - Nukunonu

Acanthurus nigricans ${ }^{1,4}$ (Linneaus, 1758) - Nukunonu

Acanthurus nigricauda ${ }^{1}$ Dunker and Mohr, 1929 - Nukunonu

Acanthurus nigros ${ }^{1,2,4}$ Günther, 1861 - Atafu, Nukunonu

Acanthurus olivaceus ${ }^{1}$ Forster in Bloch and Schneider, 1801 - Nukunonu

Acanthurus pyroferus ${ }^{1}$ Kittlitz, 1834 - Nukunonu

Acanthurus triostegus ${ }^{1,2,3}$ (Linneaus, 1758) - Atafu, Nukunonu, Fakaofo

Acanthurus xanthopterus ${ }^{1}$ Valenciennes in Cuvier and Valenciennes, 1835 - Nukunonu

Ctenochaetus striatus ${ }^{1,2,3}$ (Quoy and Gaimard, 1825) - Nukunonu, Fakaofo

Naso lituratus ${ }^{1,3}$ (Forster in Bloch and Schneider, 1801) - Nukunonu

Naso unicornis ${ }^{1,2}$ (Forsskål, 1775) - Nukunonu, Fakaofo

Zebrasoma scopas ${ }^{1}$ (Cuvier, 1829) - Nukunonu

Zebrasoma veliferum ${ }^{1}$ (Bloch, 1795) - Nukunonu

\section{Sphyraenidae}

Sphyraena barracuda ${ }^{8}$ (Edwards in Catesby, 1771) - Fakaofo

\section{Gempylidae}

Ruvettus pretiosus ${ }^{6}$ Cocco, 1833 - Fakaofo

\section{Scomberidae}

Acanthocybium solandri ${ }^{6,8}$ (Cuvier in Cuvier and Valenciennes, 1832) - Atafu, Fakaofo

Euthynnus affinis ${ }^{6,8}$ (Cantor, 1849) - Atafu, Fakaofo

Grammatorcynus bilineatus $^{8}$ (Rüppell, 1836) - Fakaofo

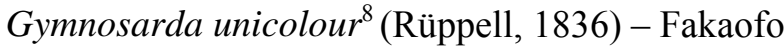

Katsuwanis pelamis ${ }^{6,7,8}$ (Linnaeus, 1758) - Atafu, Fakaofo

Thunnus alalunga ${ }^{8}$ (Bonnaterre, 1788) - Fakaofo

Thunnus albacares ${ }^{2,6,7,8}$ (Bonnaterre, 1788) - Atafu, Fakaofo

Thunnus obesus ${ }^{8}$ (Lowe, 1839) - Fakaofo

\section{Istiophoridae}

Istiophorus platypterus ${ }^{8}$ (Shaw and Nodder, 1792) - Fakaofo

Makaira nigricans ${ }^{8}$ Lacepède, 1802 - Fakaofo

\section{Bothidae}

Bothus mancus ${ }^{1,2}$ (Broussonet, 1782) - Atafu, Nukunonu, Fakaofo

Bothus pantherinus ${ }^{2}$ (Rüppell, 1830) - Fakaofo 


\section{Balistidae}

Balistapus undulatus ${ }^{1,2}$ (Park, 1797) - Atafu, Nukunonu, Fakaofo

Balistoides viridescens ${ }^{1}$ (Bloch and Schneider, 1801) - Nukunonu

Melichthys niger ${ }^{1}$ (Bloch, 1786) - Nukunonu

Melichthys vidua ${ }^{1}$ (Solander and Richardson, 1845) - Nukunonu

Pseudobalistes flavimarginatus ${ }^{1}$ (Rüppell, 1829) - Nukunonu

Rhinecanthus sp. ${ }^{2}$ - Atafu

Rhinecanthus aculeatus ${ }^{1,2}$ (Linneaus, 1758) - Atafu, Nukunonu, Fakaofo

Rhinecanthus rectangulus ${ }^{1,4}$ (Bloch and Schneider, 1801) - Nukunonu

Sufflamen bursa ${ }^{1}$ (Bloch and Schneider, 1801) - Nukunonu

\section{Monocanthidae}

Aluterus scriptus ${ }^{1,6}$ (Osbeck, 1765) - Atafu, Nukunonu

Cantherhines dumerilii ${ }^{1}$ (Hollard, 1854) - Nukunonu

\section{Tetraodontidae}

Arothron hispidus ${ }^{1}$ (Linneaus, 1758) - Nukunonu

Arothron meleagris ${ }^{1,2}$ (Lacepède, 1798) - Atafu, Nukunonu

Arothron nigropunctatus ${ }^{1}$ (Bloch and Schneider, 1801) - Nukunonu

Canthigaster amboinensis ${ }^{1}$ (Bleeker, 1865) - Nukunonu

Canthigaster janthinoptera ${ }^{2}$ (Bleeker, 1855) - Nukunonu

Canthigaster solandri ${ }^{1}$ (Richardson, 1845) - Nukunonu

\section{Diodontidae}

Diodon hystrix ${ }^{1}$ Linnaeus, 1758 - Nukunonu 


\section{REFERENCES}

Academy of Natural Sciences (ANS). 2015. Ichthyology Online Catalog. Accessed April 14. http://clade.ansp.org/ichthyology/collections/fish.php

Allen, G., and S. Bailey. 2011. Reef Fishes of the Phoenix Islands, Central Pacific Ocean. Atoll Research Bulletin, 589(3):83-118.

Allen, G., R. Steene, P. Humann, and N. DeLoach. 2003. Reef Fish Identification: Tropical Pacific. Jacksonville, Fla.: New World Publications.

Allen, G. R., and T. B. Werner. 2002. Coral Reef Fish Assessment in the "Coral Triangle" of Southeastern Asia. Environmental Biology of Fishes, 65:209-214.

Chapman, L., K. Des Rochers, and M. Pelasio. 2005. Survey of Fishing Activities in Tokelau. SPC Fisheries Newsletter, 115:36-40.

Craig, M. T., Y. J. S. de Mitcheson, and P. C. Heemstra. 2011. Groupers of the World: A Field and Market Guide. Grahamstown, South Africa: NISC (Pty) Ltd.

Elders from Atafu Atoll (Elders). 2012. Echoes at Fishermen's Rock: Traditional Tokelau Fishing. Ed. A. Hooper and I. Tinielu. Knowledges of Nature 4. Paris: UNESCO

Gillett, R. 1985. Traditional Tuna Fishing in Tokelau. South Pacific Regional Environment Programme, Topic Review No. 27. Noumea, New Caledonia: South Pacific Commission.

Gillett, R. 1990. The Mystery of the "O” Fish. SPC Fisheries Newsletter, 54:29-30

Hinds, V. T. 1971. A Rapid Fisheries Reconnaissance in the Tokelau Islands, August 18-25, 1971. Noumea, New Caledonia: South Pacific Commission.

Huntsman, J., and A. Hooper. 1996. Tokelau: A Historical Ethnography. Auckland: Auckland University Press.

Huntsman, J., and K. Kalolo. 2007. The Future of Tokelau: Decolonising Agendas 1975-2006. Auckland: Auckland University Press.

Job, S., and D. Ceccarelli. 2012. Tuvalu Marine Life: Scientific Report. Paris: Alofa Tuvalu.

McDermond, D. K., and R. Wass. 1986. Expedition Report: Baker Island, September 8-17, 1986; Howland Island, September 18-20, 1986. Administrative report of the U.S. Fish and Wildlife Service, Hawaiian/Pacific Islands NWR Complex.

McQuarrie, P. 2007. Tokelau: People, Atolls and History. Christchurch, New Zealand: MacMillan Brown Centre for Strategic Studies.

National Museum of Natural History (NMNH). 2015. "Fishes Collections" online database. Accessed April 14. http://collections.nmnh.si.edu/search/fishes/

Nelson, J. S. 2006. Fishes of the World. 4th ed. Hoboken, NJ: John Wiley and Sons.

Office for the Council of Ongoing Government (OCOG). 2010. Tokelau National Strategic Plan: 1 July 2010-30 June 2015. Apia, Samoa: Office for the Council of Ongoing Government.

Ono, R., and D. J. Addison. 2009. Ethnoecology and Tokelauan Fishing Lore from Atafu Atoll, Tokelau. SPC Marine Resource Management and Knowledge Information Bulletin, 26:3-22.

Pasilio, T., F. Pereira, K. Rikim, K. Pakoa, and I. Bertam. 2013. The Status of Reef Invertebrate Resources and Recommendations for Management at Tokelau. Noumea, New Caledonia: Secretariat of the Pacific Community.

Passfield, K. 1998. A Report of a Survey of the Marine Resources of Fakaofo Atoll, Tokelau. N.p.: Fisheries and Environmental Resource Consultants.

Randall, J. E. 1960. A New Species of Acanthurus from the Caroline Islands, with Notes on the Systematics of Other Indo-Pacific Surgeonfishes. Pacific Science, 14(3):267-279. 
Randall, J. E. 2001. Surgeonfishes of Hawai'i and the World. Honolulu: Mutual Publishing and Bishop Museum Press.

Randall, J. E. 2005. Reef and Shore Fishes of the South Pacific. Honolulu: University of Hawaii Press.

Randall, J. E., and A. Ben-Tuvia. 1983. A Review of the Groupers (Pisces: Serranidae: Epinephelinae) of the Red Sea, with Description of a New Species of Cephalopholis. Bulletin of Marine Science, 33(2):373-426.

Randall, J. E., and P. C. Heemstra. 1991. Revision of Indo-Pacific Groupers (Perciformes: Serranidae: Epinephilinae), with Descriptions of Five New Species. Indo-Pacific Fishes, 20:1-332.

Robertson, E. I., and A. C. Kibblewhite. 1966. Bathymetry around Isolated Volcanic Islands and Atolls in the South Pacific Ocean. New Zealand Journal of Geology and Geophysics, (9):1-2, 111-121. doi:10.1080/00288306.1966.10420200.

Schultz, L. P. 1943. Fishes of the Phoenix and Samoan Islands Collected in 1939 During the Expedition of the U.S.S. "Bushnell.” Bulletin of the United States National Museum 180. Washington, D.C.: Government Printing Office. doi:10.5479/si.03629236.180.i.

Simona, Ropati. 1986. Tokelau Dictionary. Apia, Samoa: Office of Tokelau Affairs.

Tuna Programme. 1983. An Assessment of the Skipjack and Baitfish Resources of Tokelau. Skipjack Survey and Assessment Programme Final Country Report No. 10. Noumea, New Caledonia: South Pacific Commission.

van Pel, H. 1958. A Survey of Fisheries in the Tokelau Islands. Noumea, New Caledonia: South Pacific Commission.

Wantiez, L., and C. Chauvet. 2003. First Data on Community Structure and Trophic Networks of Uvea Coral Reef Fish Assemblages (Wallis and Futuna, South Pacific Ocean). Cybium, 27(2):83-100.

Wass, R. C. 1984. An Annotated Checklist of the Fishes of Samoa. NOAA Technical Report SSRF781:1-43.

Williams, J. T., L. Wantiez, C. Chauvet, R. Galzin, M. Harmelin-Vivien, E. Jobet, M. Juncker, G. MouTham, S. Planes, and P. Sasal. 2006. Checklist of the Fishes of Wallis Island (Wallis and Futuna French Territories, South-Central Pacific). Cybium, 30(3):247-260.

Woodroffe, C. D., and N. Biribo. 2011. “Atolls.” In Encyclopedia of Modern Coral Reefs: Structure, Form and Process, ed. D. Hopley, pp. 1-21. Dordrecht, Netherlands: Springer.

Yaldwyn, J. C., and K. Wodzicki. 1979. Systematics and Ecology of the Land Crabs (Decapoda: Coenobitidae, Grapsidae and Gecarcinidae) of the Tokelau Islands, Central Pacific. Atoll Research Bulletin, No. 235. Washington, D.C.: Smithsonian Institution.

Zylich, K., S. Harper, and D. Zeller. 2011. "Reconstruction of Fisheries Catches for Tokelau (19502009).” In Fisheries Catch Reconstructions: Islands, Part II, ed. S. Harper and D. Zeller, pp. 107117. Fisheries Centre Research Reports 19(4). Vancouver: Fisheries Centre, University of British Columbia. 